\title{
pH-Activatable Cyanine Dyes for Selective Tumor Imaging Using Near- infrared Fluorescence and Photoacoustic Modalities
}

Huiying Mu, ${ }^{1}$ Koji Miki, ${ }^{1 *}$ Hiroshi Harada, ${ }^{2}$ Kouki Tanaka, ${ }^{1}$ Kohei Nogita, ${ }^{1}$ and Kouichi Ohe ${ }^{1 *}$

${ }^{1}$ Department of Energy and Hydrocarbon Chemistry, Graduate School of Engineering, Kyoto University, Katsura, Nishikyo-ku, Kyoto 615-8510, Japan.

${ }^{2}$ Laboratory of Cancer Cell Biology, Radiation Biology Center, Kyoto University, Yoshida, Sakyo-ku, Kyoto 606-8501, Japan.

1. Experimental Section

Index

1.1 Material and methods

1.2 Synthesis of dyes

1.3 UV-vis absorbance spectra of dyes CypH1, СурH2, СypH3, and CypHRGD

1.4 Theoretical calculation

1.5 Concentration-dependent of CypHRGD at absorption, fluorescence and PA intensity

1.6 Photophysical properties of Cyanine dye derivatives

1.7 pH-responsiveness of dyes $\mathrm{CypH2}$ and $\mathrm{CypH3}$

$1.8 \mathrm{pH}-$ dependent photoacoustic intensity of CypH3, CypHRGD and ICG

1.9 Photobleaching test of dyes

1.10 UV-vis absorption and fluorescent spectra of dye Cy-SAc-RGD

1.11 Cytotoxicity assay

1.12 In vitro cell imaging experiment: cell internalizatin

1.13 In vivo experiments

2. References

3. NMR spectra 


\section{Experimental Section}

\subsection{Materials and methods}

Dichloromethane $\left(\mathrm{CH}_{2} \mathrm{Cl}_{2}\right)$ and diethyl ether $\left(\mathrm{Et}_{2} \mathrm{O}\right)$ were purchased from Kishida Chemical Co., Ltd. (Japan). Pyridine, dimethylsulfoxide (DMSO), ethanol (EtOH), EDC $\cdot \mathrm{HCl}, 1,4$-butane sultone, glutaconaldehyde dianil hydrochloride, acetonitrile (MeCN) and Dulbecco's modified Eagle's medium (DMEM) with/without phenol red were purchased from Wako Pure Chemicals Inc. (Japan). Triton X-100, potassium carbonate $\left(\mathrm{K}_{2} \mathrm{CO}_{3}\right), N$ hydroxysuccinimide, $\mathrm{N}, \mathrm{N}$-dimethylformamide (DMF), acetone, methanol $(\mathrm{MeOH})$, chloroform $\left(\mathrm{CHCl}_{3}\right)$ were purchased form nacalai tesque (Japan). ICG was purchased from Tokyo Chemical Industry Co., Ltd., Japan. Solvents were distillated over $\mathrm{CaH}_{2}$ under $\mathrm{N}_{2}$ atmosphere. Silica gel $\left(\mathrm{SiO}_{2}, 230-400\right.$ mesh) for column chromatography was purchased from Silicycle (Canada). Buffered aqueous solutions ( $\mathrm{pH}$ 2.0-2.2) were prepared by dissolving hydrochloric acid $(\mathrm{HCl})$ and potassium chloride $(\mathrm{KCl})$ in water (MilliQ). Buffered aqueous solutions ( $\mathrm{pH}$ 3.1-6.9) were prepared by dissolving citric acid and sodium dihydrogenphosphate $\left(\mathrm{NaH}_{2} \mathrm{PO}_{4}\right)$ in water (MilliQ). Buffered aqueous solutions ( $\mathrm{pH}$ 7.2-8.7) were prepared by dissolving $\mathrm{NaH}_{2} \mathrm{PO}_{4}$ and disodium hydrogenphosphate $\left(\mathrm{Na}_{2} \mathrm{HPO}_{4}\right)$ in water (MilliQ). Buffered aqueous solutions ( $\mathrm{pH}$ 9.0-11.0) were prepared by dissolving sodium bicarbonate $\left(\mathrm{NaHCO}_{3}\right)$ and sodium carbonate $\left(\mathrm{Na}_{2} \mathrm{CO}_{3}\right)$ in water (MilliQ). All buffered aqueous solutions were stored in refrigerator and used within one week. Saline solution for in vivo experiments was purchased from Otsuka Pharmaceutical Factory, Inc. Japan. Somnopentyl was purchased from Kyoritsu Seiyaku (Japan). LysoTracker Green DND-26 was purchased from Thermo Fisher Scientific K.K. (Japan).

UV-vis absorption spectra of dyes were measured by UV-vis-NIR spectrophotometer (UH5300, Hitachi HighTechnologies Co., Japan). The sample solutions $\left(5.0 \times 10^{-6} \mathrm{M}\right)$ were prepared by mixing a solution of dyes in DMSO or DMF $\left(10 \mu \mathrm{L}, 1.5 \times 10^{-3} \mathrm{M}\right)$ with deoxygenated buffered solution $(3 \mathrm{~mL})$ with/without Triton X-100 $\left(2.0 \times 10^{-3} \mathrm{M}\right)$.

Emission spectra of dyes were measured by fluorescence spectrophotometer (RF-6000, Shimadzu Co., Japan). The sample solutions were prepared in the same manner shown in the method of UV-vis absorption measurement. Photoacoustic signals of dyes (concentration: $20 \mu \mathrm{M}$ ) in aqueous solution with different $\mathrm{pH}$ values were measured according to the reported procedure. ${ }^{1,2}$ The sample solutions were prepared in the same manner shown in the method of UV-vis absorption measurement.

High resolution mass spectra were measured by EXACTICVE (ESI, Thermo Fisher Scientific Inc., USA).

HPLC analytical experiment was performed to purify the Cyanine-cRGD conjugates by instrument equipped with HPLC column oven, UV detector (GL-7450, GL Sciences Inc., Japan) and HPLC pump (GL-7410, GL Sciences Inc., Japan).

Fluorescence imaging for in vitro cells experiments and in vivo experiments were measured by IVIS Imaging System 200 Series (PerkinElmer, Inc., USA. $\lambda_{\mathrm{ex}}=745 \mathrm{~nm}, \lambda_{\mathrm{em}}=820 \mathrm{~nm}$ ). Fluorescence intensities were quantified by Living Image 2.50-Igor Pro 4.09 software (PerkinElmer, Inc., USA.).

Photoacoustic imaging (PAI) for cells and in vivo imaging was performed on Nexus 128 scanner, which was manufactured by Endra Life Sciences (Ann Arbor, MI, USA)). 
Female BALB/c mice in 6-9 weeks of age were purchased from Japan SLC, Inc., Japan. The mice were housed at the Institute of Laboratory Animals at Graduate School of Medicine of Kyoto University. All of our animal experiments were approved by the Animal Research Committee of Kyoto University and carried out with its guidelines.

\subsection{Synthesis of dyes}
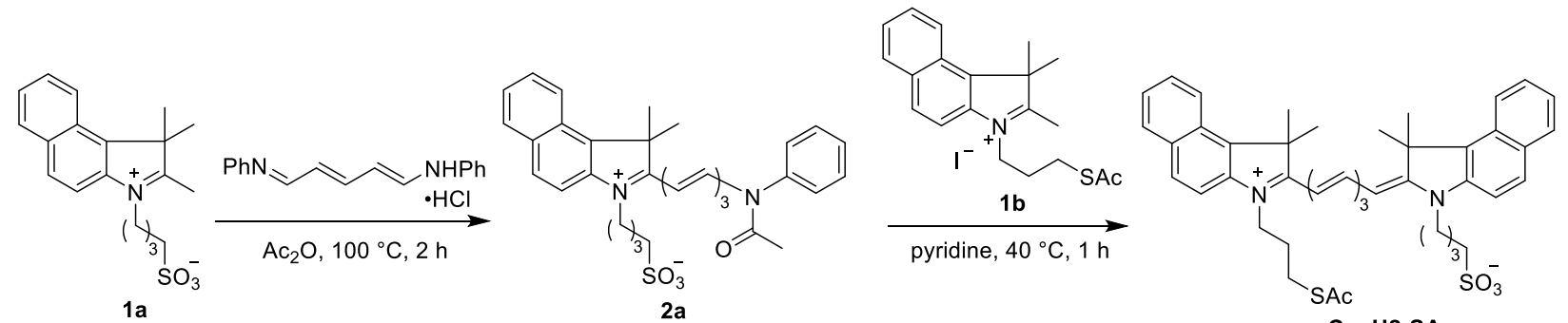

CypH2-SAc

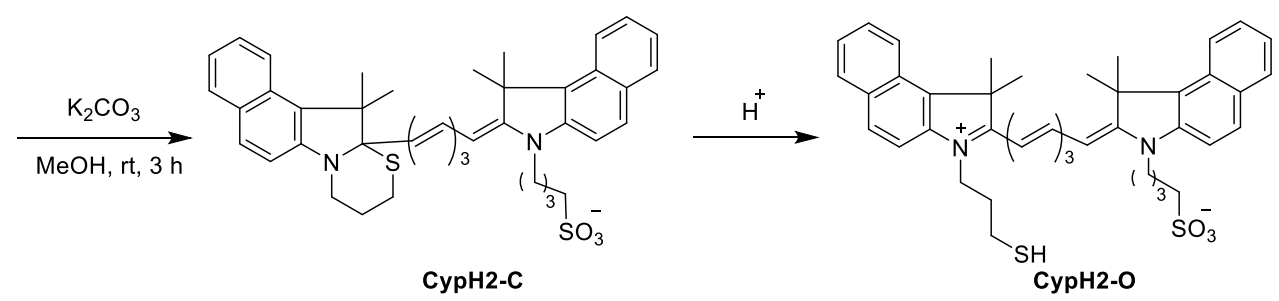

Scheme S1. Synthetic procedure of dye CypH2.
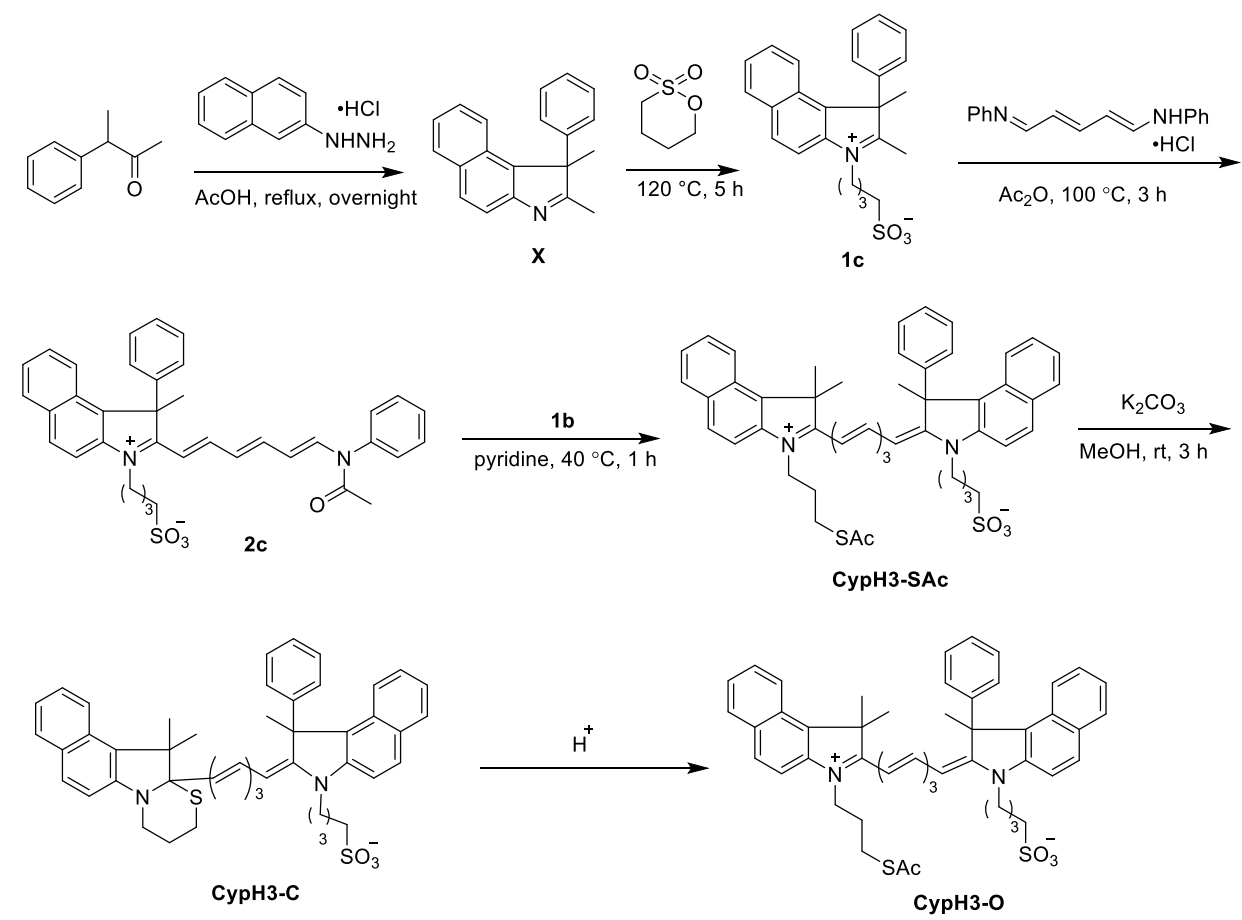

Scheme S2. Synthetic procedure of CypH3. 

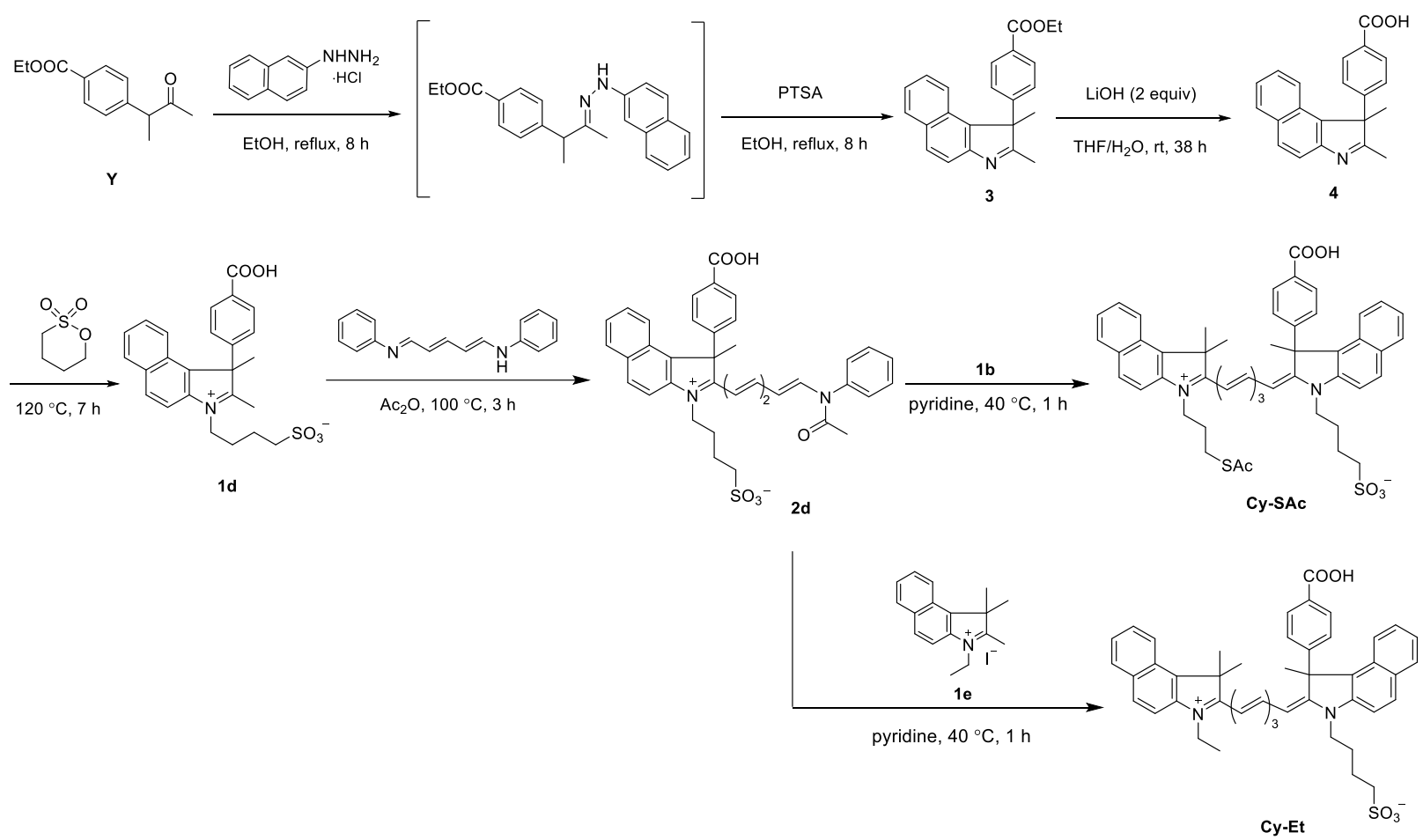

Scheme S3. Synthetic procedure of Cy-SAc and Cy-Et.

\subsubsection{Preparation of benzoindole derivatives $1 \mathrm{a}, 1 \mathrm{~b}$, and $1 \mathrm{e}$}

Benzoindole derivative 1a, 1b, and 1e were prepared according to the previous reported work. ${ }^{3}$

\subsubsection{Preparation of benzoindole derivative 1c}

3-Phenyl-2-butanone ${ }^{4}(0.63 \mathrm{~g}, 4.3 \mathrm{mmol})$ and 2-naphtylhydrazine hydrochloride $3(0.71 \mathrm{mg}, 3.7 \mathrm{mmol})$ were dissolved in $\mathrm{AcOH}(10 \mathrm{~mL})$ and refluxed overnight. After completion of the reaction with indicated by TLC $(\mathrm{DCM} / \mathrm{MeOH}=20 / 1)$, the mixture was evaporated to remove solvent and extracted by chloroform $/ \mathrm{H}_{2} \mathrm{O}$, washed with brine, dried with anhydrous sodium sulfate. The pure product $\mathbf{X}$ was obtained by column chromatography (hexane/EtOAc $=1 / 4)$ on silica gel as dark yellow solid $(0.36 \mathrm{~g}, 1.3 \mathrm{mmol}, 31 \%) . \mathbf{X}:{ }^{1} \mathrm{H} \mathrm{NMR}\left(400 \mathrm{MHz}, \mathrm{CDCl}_{3}\right.$ $\left.25^{\circ} \mathrm{C}\right) \delta 1.85(\mathrm{~s}, 3 \mathrm{H}), 2.16(\mathrm{~s}, 3 \mathrm{H}), 7.07(\mathrm{~d}, J=8.0 \mathrm{~Hz}, 2 \mathrm{H}), 7.22-7.36(\mathrm{~m}, 5 \mathrm{H}), 7.41(\mathrm{~d}, J=8.0 \mathrm{~Hz}, 1 \mathrm{H}), 7.82$ $(\mathrm{d}, J=8.0 \mathrm{~Hz}, 1 \mathrm{H}), 7.88(\mathrm{~d}, J=8.0 \mathrm{~Hz}, 2 \mathrm{H}) .{ }^{13} \mathrm{C} \mathrm{NMR}\left(100 \mathrm{MHz}, \mathrm{CDCl}_{3}, 25{ }^{\circ} \mathrm{C}\right) \delta 15.5,20.2,62.8,119.7$, 122.9, 124.6, 126.1, 126.4, 127.2, 128.1, 128.9, 129.1, 132.3, 138.7, 140.5, 151.9, 188.8. HRMS (ESI) calcd for $\mathrm{C}_{20} \mathrm{H}_{18} \mathrm{~N}\left(\mathrm{M}+\mathrm{H}^{+}\right)$272.1434, found 272.1431.

$\mathbf{X}(0.33 \mathrm{~g}, 1.2 \mathrm{mmol})$ and 1,4-butane sultone $(3.5 \mathrm{~mL})$ were added in $25 \mathrm{~mL}$ two-necked round-bottom flask and stirred at $120^{\circ} \mathrm{C}$ for $5 \mathrm{~h}$. After cooling down, cooled acetone was added to the solution. The precipitate was washed by cooled acetone to give $1 \mathrm{c}(0.24 \mathrm{~g}, 0.59 \mathrm{mmol}, 66 \%)$ as a reddish brown solid. 1c: HRMS (ESI) calcd for $\mathrm{C}_{24} \mathrm{H}_{26} \mathrm{NO}_{3} \mathrm{~S}\left(\mathrm{M}+\mathrm{H}^{+}\right) 408.1628$, found 408.1633.

The solid 1c was used for the next step without further purification. 


\subsubsection{Preparation of benzoindole derivative 1d}

$\mathbf{Y}^{5}(0.55 \mathrm{~g}, 2.5 \mathrm{mmol})$, 2-naphtylhydrazine hydrochloride $(0.83 \mathrm{~g}, 4.3 \mathrm{mmol})$ and dry ethanol $(20 \mathrm{~mL})$ were added in $50 \mathrm{~mL}$ two-necked round-bottom flask under $\mathrm{N}_{2}$ atmosphere and refluxed for $8 \mathrm{~h}$. After removal of the solvent, $p$-toluenesulfonic acid $(0.95 \mathrm{~g}, 5.5 \mathrm{mmol})$ and dry ethanol $(20 \mathrm{~mL})$ were added under $\mathrm{N}_{2}$ atmosphere and refluxed for $8 \mathrm{~h}$. After removal of the solvent, the residue was subjected to column chromatography on $\mathrm{SiO}_{2}$ as an eluent to afford $3(0.47 \mathrm{~g}, 1.4 \mathrm{mmol}, 55 \%$ for 2 steps $)$ as an orange solid. 3 : ${ }^{1} \mathrm{H}$ NMR (400 $\mathrm{MHz}, \mathrm{CDCl}_{3}$, $\left.25^{\circ} \mathrm{C}\right) \delta 1.35(\mathrm{t}, J=7.1 \mathrm{~Hz}, 3 \mathrm{H}), 1.87(\mathrm{~s}, 3 \mathrm{H}), 2.16(\mathrm{~s}, 3 \mathrm{H}), 4.34(\mathrm{q}, J=7.0 \mathrm{~Hz}, 4 \mathrm{H}), 7.03(\mathrm{~d}, J=4.1 \mathrm{~Hz}, 2 \mathrm{H})$, 7.26-7.39 (m, 3H), 7.84-7.96 (m, 5H). ${ }^{13} \mathrm{C} \mathrm{NMR}\left(100 \mathrm{MHz}, \mathrm{CDCl}_{3}, 25^{\circ} \mathrm{C}\right) \delta 14.2,15.5,20.1,60.9,62.8,119.7$, 122.6, 124.7, 126.5, 126.5, 128.0, 129.2, 129.4, 129.5, 130.2, 132.3, 140.1, 144.0, 152.0, 166.0, 187.8. HRMS (ESI) calcd for $\mathrm{C}_{23} \mathrm{H}_{22} \mathrm{NO}_{2}\left(\mathrm{M}+\mathrm{H}^{+}\right) 344.1645$, found 344.1646 .

$3(0.23 \mathrm{~g}, 0.67 \mathrm{mmol})$ and $\mathrm{THF} / \mathrm{H}_{2} \mathrm{O}(\mathrm{v} / \mathrm{v}=3 / 1,24 \mathrm{~mL})$ were added in $100 \mathrm{~mL}$ two-necked round-bottom flask under $\mathrm{N}_{2}$ atmosphere. To this solution, $1 \mathrm{M} \mathrm{LiOH}$ aqueous solution $(0.67 \mathrm{~mL} \times 3)$ was added every $30 \mathrm{~min}$ at $0{ }^{\circ} \mathrm{C}$. After stirring at room temperature for $38 \mathrm{~h}$, the solution was acidified to $\mathrm{pH}=2$ by adding $4 \mathrm{~N} \mathrm{HCl}$. The solution was extracted with $\mathrm{Et}_{2} \mathrm{O}$ and the organic layer was washed with brine $(50 \mathrm{~mL} \times 3)$ and dried over sodium sulfate to give the crude product $4(0.22 \mathrm{~g}, 0.69 \mathrm{mmol}, \sim 100 \%)$ as oily solid. 4: HRMS (ESI) calcd for $\mathrm{C}_{21} \mathrm{H}_{18} \mathrm{NO}_{2}$ $\left(\mathrm{M}+\mathrm{H}^{+}\right)$316.1332, found 316.1333.

Crude $4(0.22 \mathrm{~g}, 0.69 \mathrm{mmol})$ and 1,4-butane sultone $(3.5 \mathrm{~mL})$ were added in $25 \mathrm{~mL}$ two-necked round-bottom flask and stirred at $120^{\circ} \mathrm{C}$ for $7 \mathrm{~h}$. After cooling down, cooled acetone was added to the solution. The precipitate was collected and washed by cooled acetone to give $1 \mathbf{d}(0.24 \mathrm{~g}, 0.53 \mathrm{mmol}, 77 \%)$ as a reddish brown solid. 1d: HRMS (ESI) calcd for $\mathrm{C}_{25} \mathrm{H}_{26} \mathrm{NO}_{5} \mathrm{~S}\left(\mathrm{M}+\mathrm{H}^{+}\right)$452.1526, found 452.1527 .

The solid 1c and $\mathbf{1 d}$ can be used for the next step without further purification.

\subsubsection{Preparation of cyanine dyes derivates $\mathrm{CypH2,} \mathrm{CypH3}, \mathrm{Cy}-\mathrm{SAc}$, and $\mathrm{Cy}-\mathrm{Et}$}

1 a (38 mg, $0.11 \mathrm{mmol})$, glutaconaldehyde dianil hydrochloride $(36 \mathrm{mg}, 0.13 \mathrm{mmol})$, and $\mathrm{Ac}_{2} \mathrm{O}(2 \mathrm{~mL})$ were added in $25 \mathrm{~mL}$ two-necked round-bottom flask in $\mathrm{N}_{2}$ atmosphere under dark condition. After stirring at $100{ }^{\circ} \mathrm{C}$ for $2 \mathrm{~h}$, then cold $\mathrm{Et}_{2} \mathrm{O}(5 \mathrm{~mL})$ was poured into the mixture. The precipitate was generated after keeping the mixture at $4{ }^{\circ} \mathrm{C}$ for $1 \mathrm{~h}$. The solid was collected, washed with cooled $\mathrm{Et}_{2} \mathrm{O}$ and dried to give $2 \mathrm{a}(56 \mathrm{mg}, 0.11$ mmol, 100\%) as a dark purple solid. The freshly-prepared product $\mathbf{2 a}$ and $\mathbf{1 b}(49 \mathrm{mg}, 0.11 \mathrm{mmol})$ were dissolved in distilled pyridine $(2 \mathrm{~mL})$ in $25 \mathrm{~mL}$ two-necked round-bottom flask in $\mathrm{N}_{2}$ atmosphere under dark condition and stirred at $40{ }^{\circ} \mathrm{C}$ for $1 \mathrm{~h}$. The mixture was subjected to column chromatography on $\mathrm{SiO}_{2}$ to afford $\mathbf{C y p H 2 - S A c}$ (32 mg, $44 \mu \mathrm{mol}, 42 \%$ ) as a green solid. CypH2-SAc: ${ }^{1} \mathrm{H}$ NMR $\left(400 \mathrm{MHz}, \mathrm{CD}_{3} \mathrm{OD}, 25{ }^{\circ} \mathrm{C}\right) \delta 1.84-2.04(\mathrm{~m}$, $18 \mathrm{H}), 2.24(\mathrm{~s}, 3 \mathrm{H}), 2.81$ (t, $J=8.0 \mathrm{~Hz}, 2 \mathrm{H}), 2.90(\mathrm{t}, J=8.0 \mathrm{~Hz}, 2 \mathrm{H}), 4.10$ (t, $J=8.4 \mathrm{~Hz}, 2 \mathrm{H}), 4.13$ (t, $J=8.4 \mathrm{~Hz}$, 2H), $6.14(\mathrm{~d}, J=12.0 \mathrm{~Hz}, 1 \mathrm{H}), 6.35(\mathrm{~d}, J=12.4 \mathrm{~Hz}, 1 \mathrm{H}), 6.43-6.58(\mathrm{~m}, 2 \mathrm{H}), 7.32-7.44(\mathrm{~m}, 3 \mathrm{H}), 7.49-7.56(\mathrm{~m}$, 
4H), 7.84-8.13 (m, 8H). ${ }^{13} \mathrm{C}$ NMR (100 MHz, $\left.\mathrm{CD}_{3} \mathrm{OD}, 25{ }^{\circ} \mathrm{C}\right) \delta 17.3,23.5,25.4,27.0,27.5,27.6,27.7,29.0$, $30.6,43.7,45.2,51.7,51.9,52.5,103.6,105.6,111.7,112.3,114.1,123.3,123.4,124.0,125.7,126.2$, 127.1, 128.6, 128.7, 129.4, 129.6, 130.2, 130.3, 131.0, 131.1, 131.6, 131.9, 133.2, 133.6, 134.3, 135.3, 139.9, 141.2, 143.9, 174.4, 197.0. HRMS (ESI) calcd for $\mathrm{C}_{44} \mathrm{H}_{48} \mathrm{~N}_{2} \mathrm{O}_{4} \mathrm{~S}_{2} \mathrm{Na}\left(\mathrm{M}+\mathrm{Na}^{+}\right)$755.2948, found 755.2950.

Deprotection of CypH2-SAc: CypH2-SAc $(1.5 \mathrm{mg}, 2.1 \mu \mathrm{mol})$, and potassium carbonate $(0.79 \mathrm{mg}, 5.8 \mu \mathrm{mol})$ were dissolved in $\mathrm{MeOH}(2 \mathrm{~mL})$ and stirred at room temperature for $3 \mathrm{~h}$ in a sample bottle. After removal of the solvent, the residue was diluted with $\mathrm{CH}_{2} \mathrm{Cl}_{2}(10 \mathrm{~mL})$. The organic solution was washed with saturated $\mathrm{NaHCO}_{3}$ aqueous solution $(10 \mathrm{~mL} \times 2)$. The organic solvent was removed under reduced pressure to obtain CypH2. CypH2: a yellow solid (quant.): ${ }^{1} \mathrm{H}$ NMR $\left(400 \mathrm{MHz}, \mathrm{CD}_{3} \mathrm{OD}, 25^{\circ} \mathrm{C}\right) \delta 1.11(\mathrm{~s}, 3 \mathrm{H}), 1.63(\mathrm{~s}, 3 \mathrm{H}), 1.85-1.96(\mathrm{~m}$, $12 \mathrm{H}), 2.42-2.46(\mathrm{~m}, 1 \mathrm{H}), 2.88(\mathrm{t}, J=8.0 \mathrm{~Hz}, 2 \mathrm{H}), 3.00-3.04(\mathrm{~m}, 1 \mathrm{H}), 3.53-3.58(\mathrm{~m}, 1 \mathrm{H}), 3.77(\mathrm{t}, J=8.4 \mathrm{~Hz}$, 2H), 3.87-3.90 (m, 1H), $5.47(\mathrm{~d}, J=12.0 \mathrm{~Hz}, 1 \mathrm{H}), 5.86(\mathrm{~d}, J=15.6 \mathrm{~Hz}, 1 \mathrm{H}), 6.11(\mathrm{t}, J=12.0 \mathrm{~Hz}, 1 \mathrm{H}), 6.36(\mathrm{t}$, $J=12.4 \mathrm{~Hz}, 1 \mathrm{H}), 6.52(\mathrm{t}, J=12.8 \mathrm{~Hz}, 1 \mathrm{H}), 6.95-7.21(\mathrm{~m}, 6 \mathrm{H}), 7.34-7.42(\mathrm{~m}, 2 \mathrm{H}), 7.70-8.01(\mathrm{~m}, 6 \mathrm{H}) .{ }^{13} \mathrm{C} \mathrm{NMR}$ (400 MHz, $\mathrm{CD}_{3} \mathrm{OD}$ with little amount $\mathrm{CDCl}_{3}, 25^{\circ} \mathrm{C}$ ) $\delta 22.3,25.5,26.5,40.9,41.5,44.5,45.8,47.1,50.6,50.9$, $51.2,51.7,52.1,53.0,88.1,96.0,108.8,110.9,120.9,121.0,121.1,121.4,124.5,125.6,126.1$, 126.7, 127.7 , 127.9, 128.4, 128.9, 129.0, 129.1, 129.2, 129.4, 130.4, 130.6, 135.5, 137.1, 142.1, 145.6, 157.1, 159.9. (HRMS (ESI) calcd for $\mathrm{C}_{42} \mathrm{H}_{45} \mathrm{~N}_{2} \mathrm{O}_{3} \mathrm{~S}_{2}\left(\mathrm{M}^{-}\right) 689.2877$, found 689.2868.

CypH3 and Cy-SAc were obtained in similar manner using benzoindole derivatives 1c and $\mathbf{1 d}$.

2c as purple solid (48\%): HRMS calcd for $\mathrm{C}_{37} \mathrm{H}_{36} \mathrm{~N}_{2} \mathrm{O}_{4} \mathrm{SNa}\left(\mathrm{M}+\mathrm{Na}^{+}\right) 627.2288$, found 627.2286.

CypH3-SAc: green solid (17\%), ${ }^{1} \mathrm{H}$ NMR $\left(400 \mathrm{MHz}, \mathrm{CD}_{3} \mathrm{OD}, 25{ }^{\circ} \mathrm{C}\right) \delta 1.81(\mathrm{~s}, 3 \mathrm{H}), 1.83(\mathrm{~s}, 3 \mathrm{H}), 1.95-2.01$ (m, 6H), $2.06(\mathrm{~s}, 3 \mathrm{H}), 2.20(\mathrm{~s}, 3 \mathrm{H}), 2.84-2.90(\mathrm{~m}, 4 \mathrm{H}), 4.13(\mathrm{t}, J=7.1 \mathrm{~Hz}, 2 \mathrm{H}), 4.18(\mathrm{t}, J=7.1 \mathrm{~Hz}, 2 \mathrm{H}), 6.15-$ $6.19(\mathrm{~m}, 2 \mathrm{H}), 6.27-6.39(\mathrm{~m}, 2 \mathrm{H}), 7.16-7.58(\mathrm{~m}, 14 \mathrm{H}), 7.74(\mathrm{~d}, J=6.7 \mathrm{~Hz}, 1 \mathrm{H}), 7.85-7.89(\mathrm{~m}, 4 \mathrm{H}), 8.09(\mathrm{~d}, J=$ $8.7 \mathrm{~Hz}, 1 \mathrm{H}) .{ }^{13} \mathrm{C} \mathrm{NMR}\left(400 \mathrm{MHz}, \mathrm{CD}_{3} \mathrm{OD}\right.$ with little amount $\left.\mathrm{CDCl}_{3}, 2{ }^{\circ} \mathrm{C}\right) \delta 23.7,26.2,26.9,27.5,27.7,29.1$, $30.6,43.2,44.0,44.9,51.8,52.3,58.7,104.8,111.9,112.1,114.7,122.7,123.4,125.5,125.9,126.1,126.4,127.3$, 128.0, 128.4, 128.7, 128.9, 129.3, 129.5, 129.9, 130.4, 130.6, 131.1, 131.5, 131.6, 131.7, 132.0, 133.2, 133.4, 135.0, 135.3, 140.9, 141.5, 143.2, 152.4, 156.8, 174.9, 196.9. (HRMS (ESI) calcd for $\mathrm{C}_{49} \mathrm{H}_{50} \mathrm{~N}_{2} \mathrm{O}_{4} \mathrm{~S}_{2} \mathrm{Na}\left(\mathrm{M}+\mathrm{Na}^{+}\right.$) 817.3104, found 817.3098.

CypH3 as brown solid (quant): ${ }^{1} \mathrm{H}$ NMR $\left(400 \mathrm{MHz}, \mathrm{CD}_{3} \mathrm{OD}, 25^{\circ} \mathrm{C}\right) \delta 1.07(\mathrm{~s}, 3 \mathrm{H}), 1.19(\mathrm{~s}, 1 \mathrm{H}), 1.60(\mathrm{~s}, 3 \mathrm{H})$, 1.90-1.99 (m, 6H), 2.10 (s, 3H), 2.86-2.99 (m, 4H), $3.86(\mathrm{t}, J=7.8 \mathrm{~Hz}, 3 \mathrm{H}), 5.40$ (d, $J=12.0 \mathrm{~Hz}, 1 \mathrm{H}), 5.78(\mathrm{~d}$, $J=12.4 \mathrm{~Hz}, 1 \mathrm{H}), 5.93(\mathrm{t}, J=12.0 \mathrm{~Hz}, 1 \mathrm{H}), 6.09$ (t, $J=12.0 \mathrm{~Hz}, 1 \mathrm{H}), 6.22(\mathrm{t}, J=12.8 \mathrm{~Hz}, 1 \mathrm{H}), 6.32(\mathrm{t}, J=12.0$ $\mathrm{Hz}, 1 \mathrm{H}), 6.82(\mathrm{t}, J=10.3 \mathrm{~Hz}, 1 \mathrm{H}), 7.05-7.48(\mathrm{~m}, 15 \mathrm{H}), 7.69$ (d, $J=8.7 \mathrm{~Hz}, 2 \mathrm{H}), 7.75(\mathrm{~d}, J=8.3 \mathrm{~Hz}, 2 \mathrm{H}), 7.90$ $(\mathrm{d}, J=7.6 \mathrm{~Hz}, 1 \mathrm{H}) .{ }^{13} \mathrm{C} \mathrm{NMR}\left(400 \mathrm{MHz}, \mathrm{CD}_{3} \mathrm{OD}\right.$ with little amount $\left.\mathrm{CDCl}_{3}, 2{ }^{\circ} \mathrm{C}\right) \delta 20.4,22.3,23.9,25.5,26.2$, 29.3, 41.5, 44.3, 45.7, 50.8, 51.5, 51.9, 52.8, 87.9, 96.4, 108.8, 110.8, 120.7, 120.8, 121.0, 121.3, 124.6, 125.5, $125.9,126.0,126.5,126.7,127.7,127.8,127.9,128.1,128.2,128.6,128.7,128.9,129.1,129.2,129.3,130.2$, 130.5, 135.3, 136.9, 142.3, 145.0, 145.5, 157.3, 159.8. HRMS (ESI) calcd for $\mathrm{C}_{47} \mathrm{H}_{47} \mathrm{~N}_{2} \mathrm{O}_{3} \mathrm{~S}_{2}\left(\mathrm{M}^{-}\right) 751.3034$, found 751.3022 .

2d as purple solid (88\%): HRMS calcd for $\mathrm{C}_{38} \mathrm{H}_{36} \mathrm{~N}_{2} \mathrm{O}_{6} \mathrm{SNa}\left(\mathrm{M}+\mathrm{Na}^{+}\right)$671.2186, found 671.2166. 
Cy-SAc: a green solid (96\%): ${ }^{1} \mathrm{H}$ NMR $\left(400 \mathrm{MHz}, \mathrm{CD}_{3} \mathrm{OD}, 25^{\circ} \mathrm{C}\right) \delta 1.80(\mathrm{~s}, 3 \mathrm{H}), 1.83(\mathrm{~s}, 3 \mathrm{H}), 1.92-2.00(\mathrm{~m}$, $6 \mathrm{H}), 2.09(\mathrm{~s}, 3 \mathrm{H}), 2.20(\mathrm{~s}, 3 \mathrm{H}), 2.85-2.91(\mathrm{~m}, 4 \mathrm{H}), 4.16-4.18(\mathrm{~m}, 4 \mathrm{H}), 6.09(\mathrm{~d}, J=8.4 \mathrm{~Hz}, 1 \mathrm{H}), 6.23-6.41(\mathrm{~m}$, $3 \mathrm{H}), 7.11-7.18(\mathrm{~m}, 4 \mathrm{H}), 7.40-8.12(\mathrm{~m}, 15 \mathrm{H}) .{ }^{13} \mathrm{C} \mathrm{NMR}\left(100 \mathrm{MHz}, \mathrm{CD}_{3} \mathrm{OD}, 25{ }^{\circ} \mathrm{C}\right) \delta 23.7,26.1,26.9,27.4,27.5$, 29.2, 30.6, 33. 0, 44.3, 44.8, 51.9, 52.6, 58.4, 103.7, 105.6, 105.8, 112.0, 112.1, 122.6, 123.4, 125.5, 125.7, 126.3, $126.9,127.3,128.0,128.5,128.8,129.2,129.3,129.6,129.8,130.6,131.1,131.6,131.7,131.8,132.1,133.0$, 133.5, 134.3, 135.5, 140.7, 141.8, 147.6, 151.2, 153.3, 172.4, 175.9, 197.1. HRMS (ESI) calcd for $\mathrm{C}_{50} \mathrm{H}_{50} \mathrm{~N}_{2} \mathrm{O}_{6} \mathrm{~S}_{2}$ $\left(\mathrm{M}+\mathrm{Na}^{+}\right)$861.3002, found 861.3003.

Cy-Et: a green solid (95\%): ${ }^{1} \mathrm{H}$ NMR $\left(400 \mathrm{MHz}, \mathrm{CD}_{3} \mathrm{OD}, 25^{\circ} \mathrm{C}\right) \delta 1.41(\mathrm{t}, J=7.8 \mathrm{~Hz}, 3 \mathrm{H}), 1.88(\mathrm{~s}, 3 \mathrm{H}), 1.91$ (s, 3H), 2.01-2.04 (m, 4H), $2.15(\mathrm{~s}, 3 \mathrm{H}), 2.94(\mathrm{t}, J=7.4 \mathrm{~Hz}, 2 \mathrm{H}), 4.18-4.25(\mathrm{~m}, 4 \mathrm{H}), 6.06(\mathrm{~d}, J=13.2 \mathrm{~Hz}, 1 \mathrm{H})$, 6.28-6.47 (m, 3H), 7.07-7.23 (m, 3H), 7.44-7.63 (m, 7H), 7.79 (d, J=8.0 Hz, 1H), 7.91-8.04 (m, 6H), 8.15 (d, $J=8.4 \mathrm{~Hz}, 2 \mathrm{H}) .{ }^{13} \mathrm{C} \mathrm{NMR}\left(100 \mathrm{MHz}, \mathrm{CD}_{3} \mathrm{OD}, 25^{\circ} \mathrm{C}\right) \delta 13.1,14.4,23.4,26.1,27.5,32.3,40.4,51.6,52.3,57.9$, $61.4,102.8,103.5,105.3,111.5,111.6,122.3,123.1,125.3,126.2,126.7,127.2,127.4,128.3,128.6,128.9$, 129.0, 130.3, 130.4, 130.9, 131.3, 131.7, 131.8, 132.5, 133.3, 133.8, 135.5, 139.9, 141.3, 146.5, 147.7, 150.4, 151.8, 153.0, 156.4, 172.8, 175.4. HRMS (ESI) calcd for $\mathrm{C}_{47} \mathrm{H}_{46} \mathrm{~N}_{2} \mathrm{O}_{5} \mathrm{~S}\left(\mathrm{M}-\mathrm{H}^{-}\right)$749.3055, found 749.3047.

\subsubsection{Synthesis of cRGD conjugates with Cyanine dye (Cy-SAc-RGD and CyRGD)}

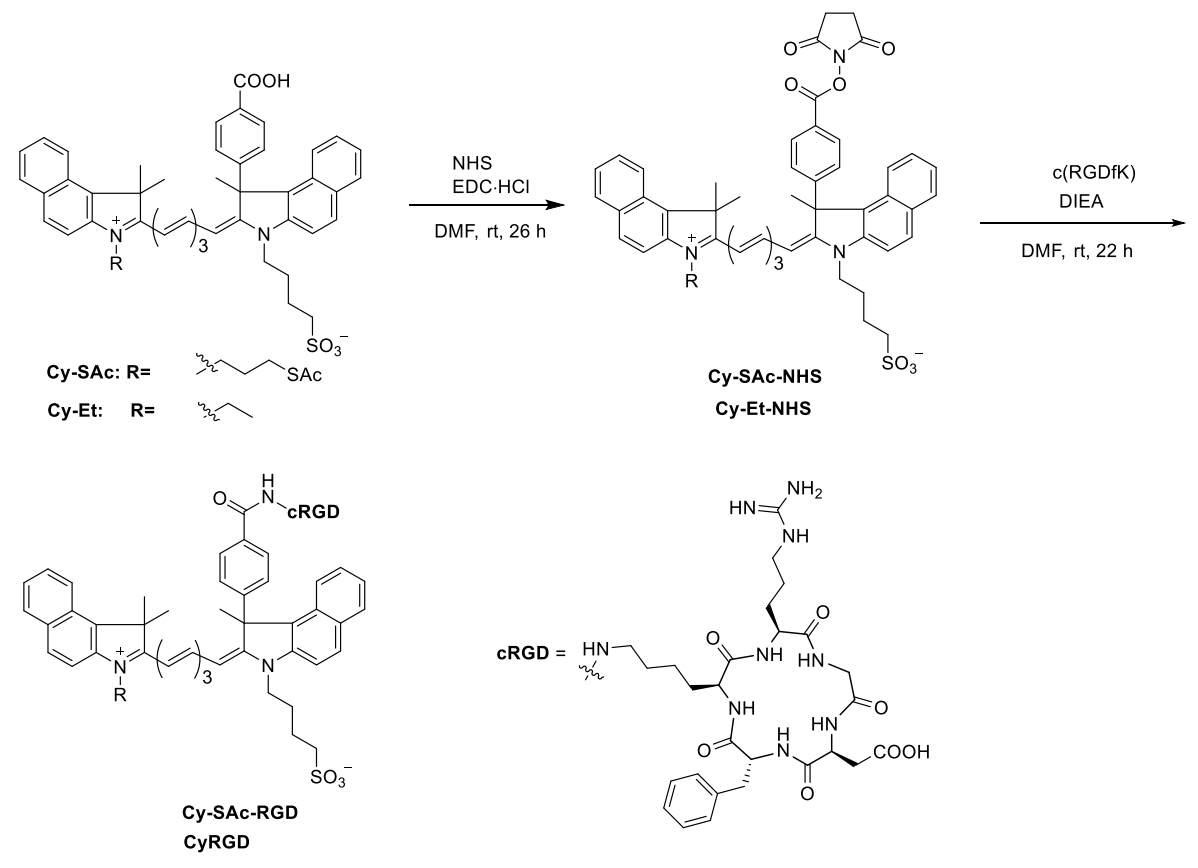

Scheme S4. Synthesis of Cy-SAc-RGD and CyRGD.

Preparation of Cy-NHS ester: To a $25 \mathrm{~mL}$ flask, Cy-Et $(23 \mathrm{mg}, 31 \mu \mathrm{mol})$, EDC $\cdot \mathrm{HCl}(8.8 \mathrm{mg}, 57 \mu \mathrm{mol})$ and $N$-hydroxysuccinimide (11 mg, $96 \mu \mathrm{mol}$ ) were dissolved in dehydrated DMF ( $3 \mathrm{~mL}$ ) under $\mathrm{N}_{2}$ atmosphere and the mixture was stirred at room temperature for $20 \mathrm{~h}$ in the dark. The ending of reaction was monitored by TLC $(\mathrm{DCM} / \mathrm{MeOH}=10 / 1)$. After removal of the solvent under reduced pressure, the residue was purified by flash 
column chromatography to yield Cy-Et-NHS as a green solid. The crude Cy-NHS ester can be used for next step without further purification and characterization. Cy-SAc-NHS: green solid (84\%), HRMS (ESI) calcd for $\mathrm{C}_{54} \mathrm{H}_{53} \mathrm{~N}_{3} \mathrm{O}_{8} \mathrm{~S}_{2} \mathrm{Na}\left(\mathrm{M}+\mathrm{Na}^{+}\right)$958.3166, found 958.3165. Similar procedure was conducted to obtain pure Cy-SAcNHS. Cy-Et-NHS: green solid (89\%), HRMS (ESI) calcd for $\mathrm{C}_{51} \mathrm{H}_{49} \mathrm{~N}_{3} \mathrm{O}_{7} \mathrm{~S}\left(\mathrm{M}-\mathrm{H}^{-}\right)$846.3218, found 846.3212. cRGD conjugation: Cy-Et-NHS (10 mg, $12 \mu \mathrm{mol})$, DIEA (10 $\mu \mathrm{L}, 0.15 \mathrm{mmol})$, c(RGDfK $)^{6}(16 \mathrm{mg}, 23 \mu \mathrm{mol})$ and dry DMF $(2.7 \mathrm{~mL})$ were added in $25 \mathrm{~mL}$ two-necked round-bottom flask under $\mathrm{N}_{2}$ atmosphere in the dark. After stirred at room temperature for $22 \mathrm{~h}$, the solvent was removed under reduced pressure and the residue was isolated by HPLC analysis (YMC-Triart Phenyl column $250 \times 4.6 \mathrm{~mm} 5 \mu \mathrm{m}$ (YMC Co., Ltd, Japan), 50-100\% of acetonitrile in ammonium acetate buffer $(1 \mathrm{~mL} / \mathrm{min}), \mathrm{UV}$ detected at $250 \mathrm{~nm})$ to afford CyRGD $(6.1 \mathrm{mg}, 4.3$ $\mu \mathrm{mol}, 37 \%)$ as a green solid. Similar isolated procedure was conducted to obtain pure Cy-SAc-RGD (22\%). Cy-SAc-RGD HRMS (ESI) calcd for $\mathrm{C}_{77} \mathrm{H}_{89} \mathrm{~N}_{11} \mathrm{O}_{12} \mathrm{~S}_{2}\left(\mathrm{M}-\mathrm{H}^{-}\right)$1422.6061, found 1422.6056. CyRGD HRMS (ESI) calcd for $\mathrm{C}_{74} \mathrm{H}_{84} \mathrm{~N}_{11} \mathrm{O}_{11} \mathrm{~S}\left(\mathrm{M}+\mathrm{H}^{+}\right)$1336.6223, found 1336.6194.
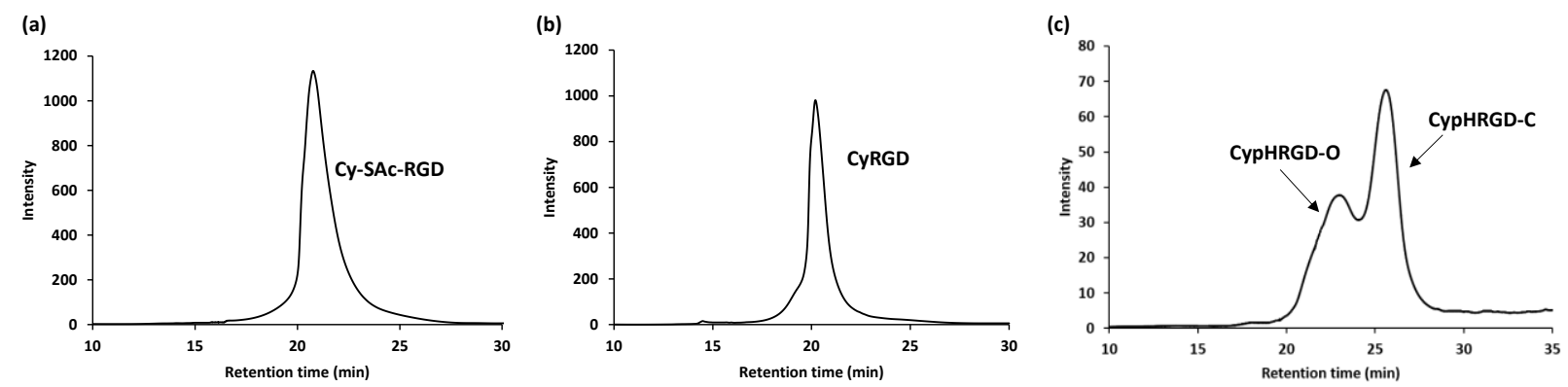

Figure S1. UV-vis trace of HPLC chromatogram of (a) Cy-SAc-RGD, (b) CyRGD and (c) CypHRGD. The retention time for Cy-SAc-RGD, CyRGD was assigned as $20.9 \mathrm{~min}$ and $20.1 \mathrm{~min}$, respectively. The probe CypHRGD is in an equilibrium between CypHRGD-C having a closed-ring structure and CypHRGD-O having a ring-open structure.
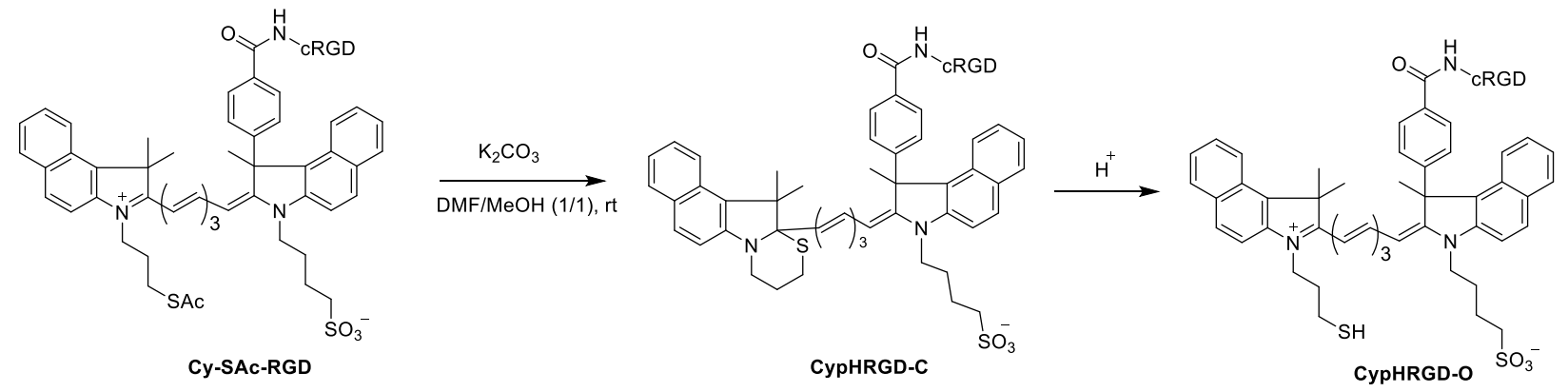

Scheme S5. Deprotection of Cy-SAc-RGD.

The similar deprotection procedure for Cy-SAc-RGD in a mixture of DMF/MeOH $(1 / 1, \mathrm{v} / \mathrm{v})$ was conducted to yield pH-responsive probe CypHRGD as a brown solid. After removed the solvents under reduced pressure, the residue was purified by HPLC analysis (YMC-Triart Phenyl column $250 \times 4.6 \mathrm{~mm}$, acetonitrile/ammonium 
acetate buffer $(1 \mathrm{~mL} / \mathrm{min}$ ), UV detected at $250 \mathrm{~nm}$ ) to afford CypHRGD (Figure S1c). HRMS (ESI) of CypHRGD-O calcd for $\mathrm{C}_{75} \mathrm{H}_{86} \mathrm{~N}_{11} \mathrm{O}_{11} \mathrm{~S}_{2}\left(\mathrm{M}-\mathrm{H}^{-}\right)$1380.5955, found 1380.5982; HRMS (ESI) of CypHRGD-C calcd for $\mathrm{C}_{75} \mathrm{H}_{85} \mathrm{~N}_{11} \mathrm{O}_{11} \mathrm{~S}_{2}\left(\mathrm{M}-\mathrm{H}^{-}\right)$1379.5877, found 1379.5829 .

\subsection{UV-vis absorbance spectra of dyes CypH1, СуpH2, СуpH3, and CypHRGD}
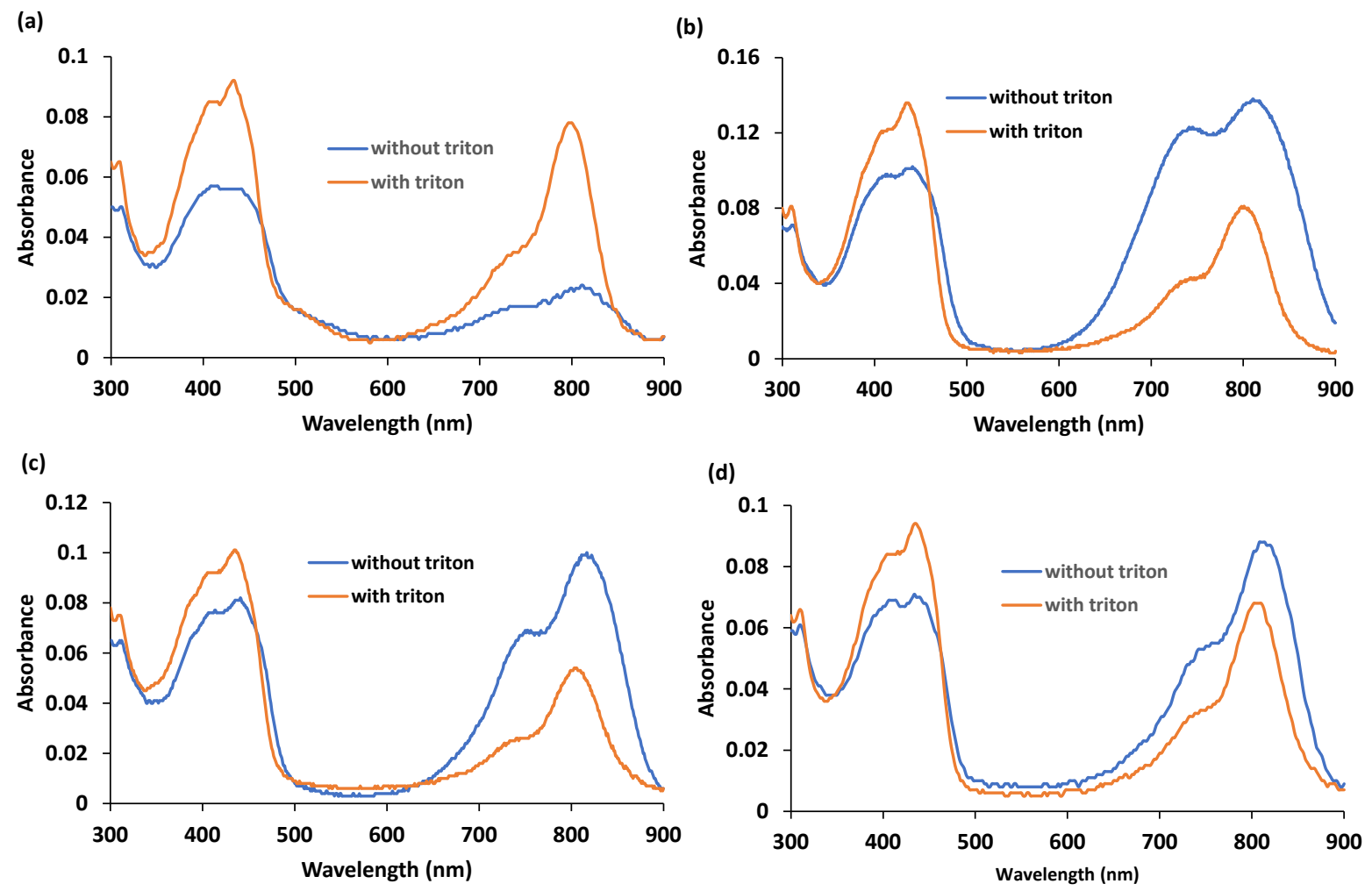

Figure S2. UV-vis absorbance spectra of (a) CypH1, (b) CypH2, (c) CypH3 and (d) CypHRGD (5 $\mu$ M) in buffered solutions $(\mathrm{pH}=7.2,0.1 \mathrm{M})$ without (blue line) and with Triton $\mathrm{X}-100$ (orange line, $2 \times 10^{-3} \mathrm{M}$ ).

\subsection{Theoretical calculation}

The density function theory (DFT) calculations were performed for the geometry optimization of the opening form of CypH1 and CypH3 derivatives at the B3LYP/6-31G(d) level ${ }^{7}$ by using Gaussian 09 package. ${ }^{8}$ Cartesian coordinates of all compounds are shown at the end of the SI. 


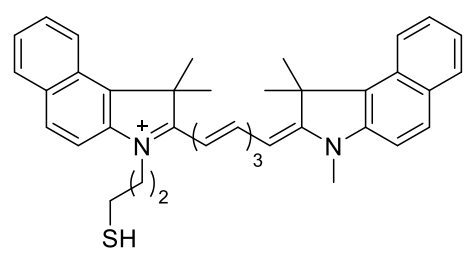

CypH1-O derivative
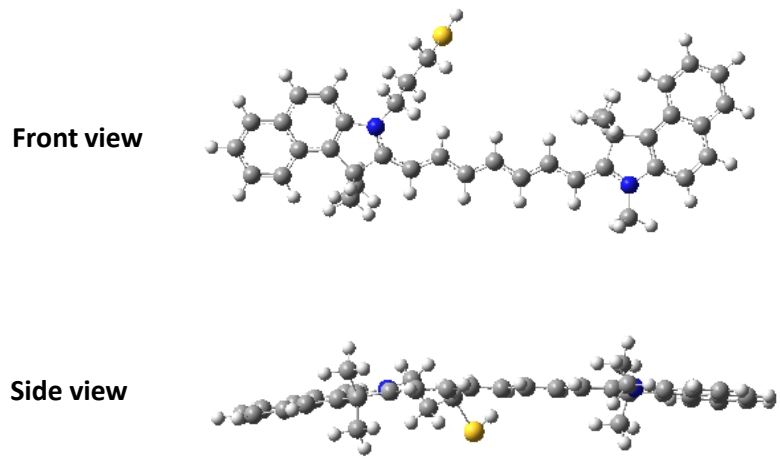

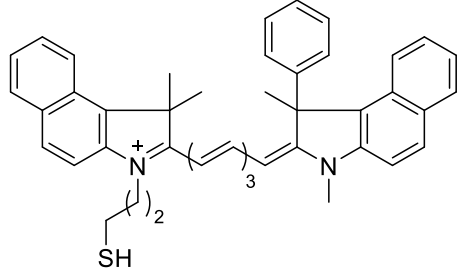

CypH3-O derivative
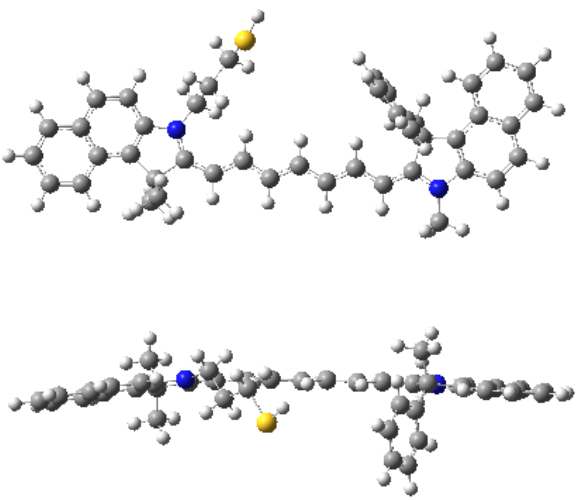

Figure S3. The calculated opening-form structures of СypH1 and СypH3 derivatives and their optimized structures.

\subsection{Concentration-dependence of CypHRGD at absorption, fluorescence and PA intensity}
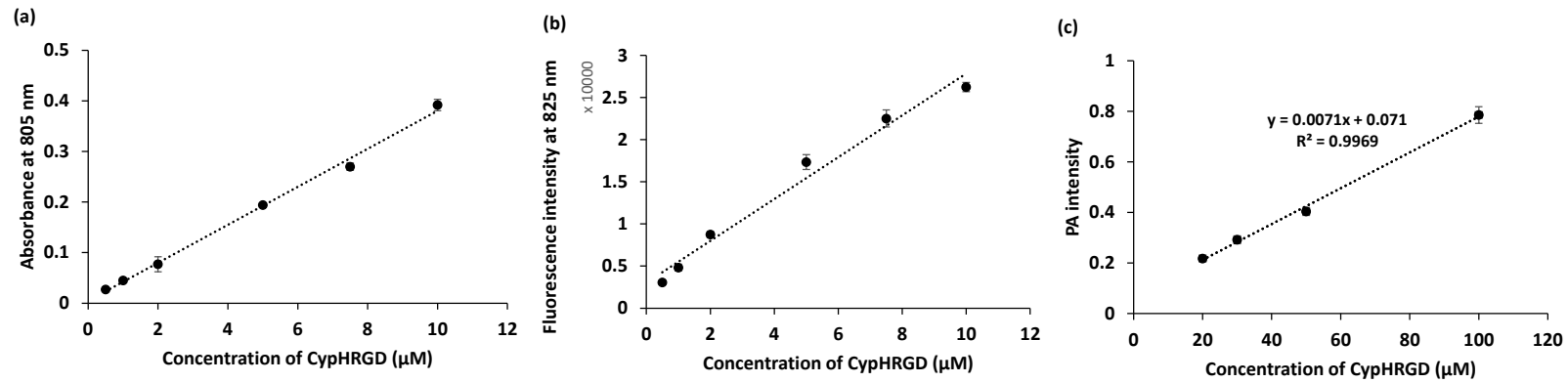

Figure S4. Concentration effect of CypHRGD. (a) Absorption at $805 \mathrm{~nm}$ and (b) fluorescence intensity at 825 $\mathrm{nm}$ versus the concentration of CypHRGD at a range of 0.5-10 $\mu \mathrm{M}$. (c) Photoacoustic signals in linear of 20$100 \mu \mathrm{M}$ CypHRGD. The used solution was PBS solution (pH 5.0, 0.1 M).

\subsection{Photophysical properties of Cyanine dye derivatives}

Molar extinction coefficient values and relative quantum yields in EtOH were measured (Table S1). Relative quantum yields were determined by using the reported method. Due to low absorbance intensity of CypH3 and CypHRGD in EtOH, molar extinction coefficients of them are not determined. Relative quantum yields of CypH3-SAc, CyRGD, and CySAc-RGD were similar to that of ICG. The quantum yield of CypH3 and 
CypHRGD might be underestimated, because closed forms were a major component in EtOH.

Table S1. Photophysical properties of dyes.

\begin{tabular}{lcc}
\hline Dyes & $\begin{array}{c}\text { molar extinction coefficient } \\
\varepsilon\left(\mathrm{L} \cdot \mathrm{mol}^{-1} \cdot \mathrm{cm}^{-1}\right)\end{array}$ & $\begin{array}{c}\text { fluorescence quantum yield } \\
\Phi(\%)\end{array}$ \\
\hline CypH3-SAc & $2.1 \times 10^{5}$ & 11.30 \\
CypH3 & $\mathrm{nd}$ & 4.25 \\
CyRGD & $2.0 \times 10^{5}$ & 11.91 \\
CySAc-RGD & $1.9 \times 10^{5}$ & 11.35 \\
CypHRGD & $\mathrm{nd}$ & 4.39 \\
\hline
\end{tabular}

a) Determined at $785 \mathrm{~nm}$. b) Indocyanine green (ICG, $\Phi=13.2 \%(\mathrm{EtOH})$ ) was used as a standard.

\section{$1.7 \mathrm{pH}-$ responsiveness of dyes $\mathrm{CypH} 2$ and $\mathrm{CypH3}$}

The UV-vis absorption and fluorescence spectra of СурН2 and СурН3 in PBS buffered solutions with different $\mathrm{pH}$ value were examined and summarized in Figure S5a-5b and S5d-5e. The fluorescence intensity of СурH2 and CypH3 were fitted to sigmoid curves to determine $\mathrm{p} K_{\mathrm{a}}$ values (Figure $\mathrm{S} 5 \mathrm{c}$ and Figure $5 \mathrm{f}$ ).
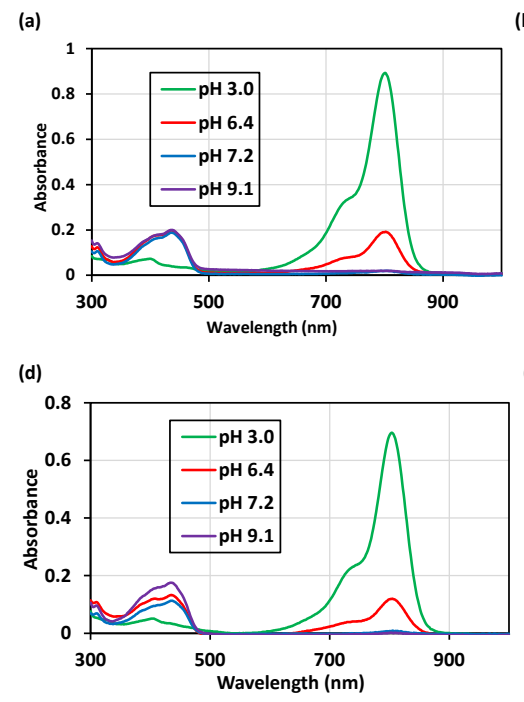
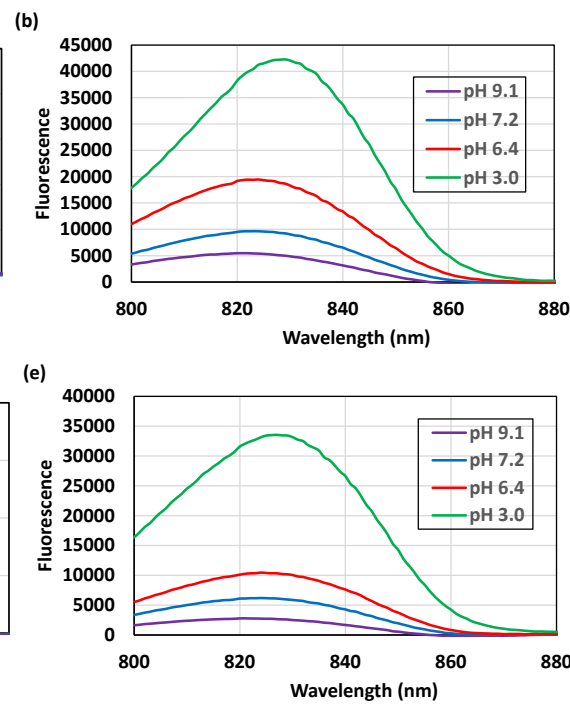
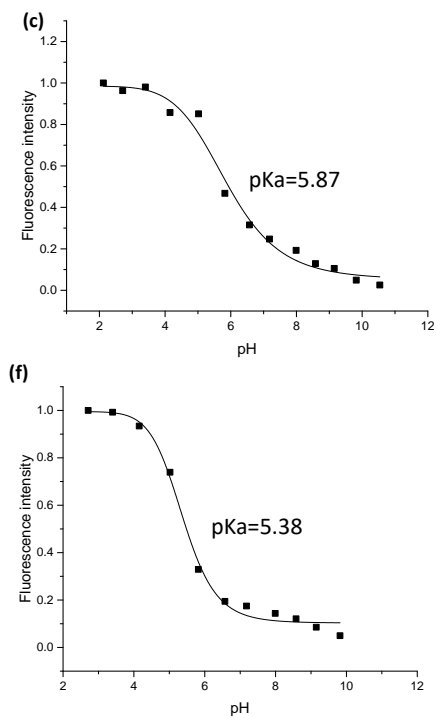

Figure S5. UV-vis absorption and fluorescence spectra of (a, b) СурH2 and (d, e) CypH3 (5 $\mu \mathrm{M})$ in buffered solutions with Triton X-100 (2 $\left.\times 10^{-3} \mathrm{M}\right)$. Fluorescence intensities of (c) $\mathbf{C y p H 2}$ and (f) CypH3 in buffered aqueous solutions with different $\mathrm{pH}$ values normalized at $820 \mathrm{~nm}\left(\lambda_{\mathrm{ex}}=780 \mathrm{~nm}\right)$. The $\mathrm{p} K_{\mathrm{a}}$ values were determined by fitting fluorescence intensities to sigmoid curves $\left(\mathbf{C y p H 2}: \mathrm{R}^{2}=0.993, \mathbf{C y p H 3}: \mathrm{R}^{2}=0.994\right)$.

\section{$1.8 \mathrm{pH}-d e p e n d e n t$ photoacoustic intensity of CypH3, CypHRGD and ICG}

The pH-dependent PA intensity (irradiated with pulsed wave at $800 \mathrm{~nm}$ ) and color changes of CypH3, 
CypHRGD and ICG in PBS buffered solutions with different $\mathrm{pH}$ value were examined and summarized in Figure S6a and Figure S6b. The PA intensity of CypHRGD were fitted to sigmoid curves to determine $\mathrm{p} K_{\mathrm{a}}$ values (Figure $\mathrm{S} 7$ ).

(a)

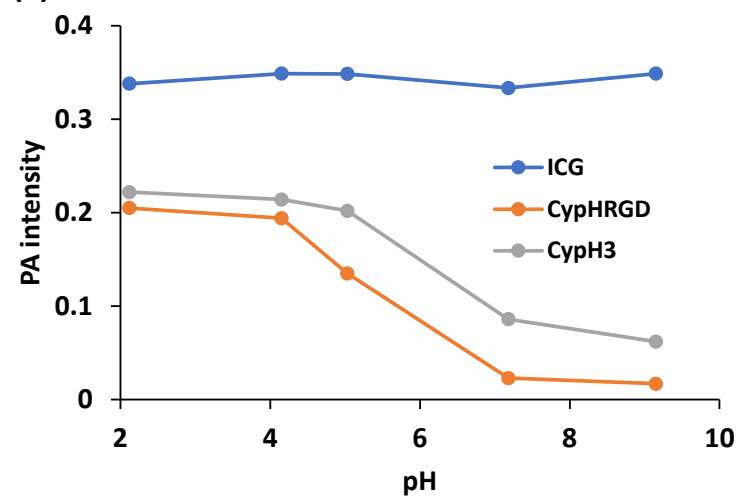

(b)

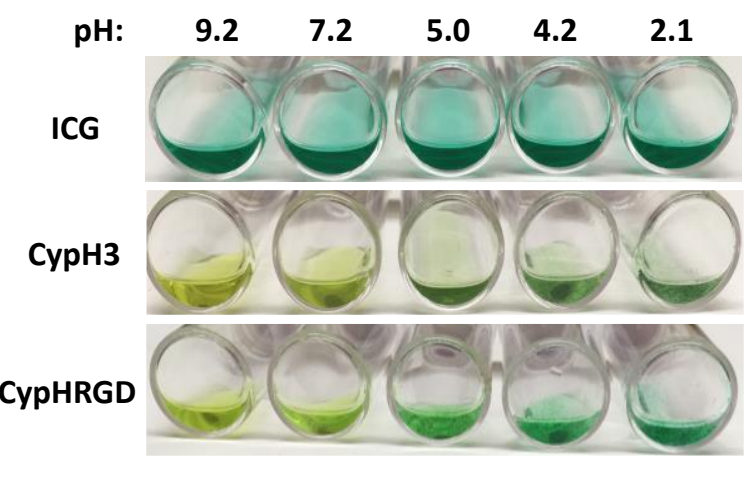

Figure S6. (a) PA intensity and (b) color change of dyes CypH3 (gray), CypHRGD (orange) and ICG (blue) in different $\mathrm{pH}$ buffered solutions. The concentration of dyes is $20 \mu \mathrm{M}$.

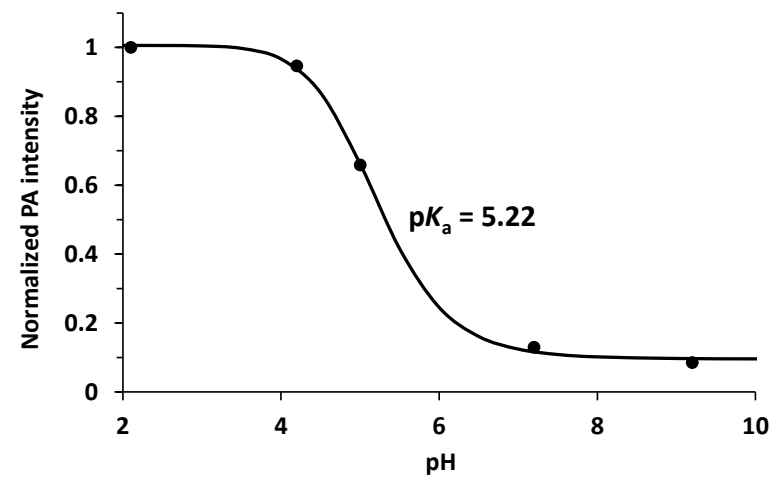

Figure S7. The normalized PA intensities of CypHRGD in buffered aqueous solutions with different $\mathrm{pH}$ values. The $\mathrm{p} K_{\mathrm{a}}$ values were determined by PA intensities to sigmoid curves $\left(\mathrm{R}^{2}=0.999\right)$.

\subsection{Photobleaching test of dyes}

The photostability of dyes CypH3-SAc, CypH3, and ICG was evaluated. Solutions of dyes were dissolved in EtOH $\left(5.0 \times 10^{-6} \mathrm{M}, 3 \mathrm{~mL}\right)$. All solutions were transferred into quartz cells in air and irradiated using a $150 \mathrm{~W}$ Xenon light source (MAX-150, Asahi Spectra Co., Ltd., Japan, illuminance: $20 \mu \mathrm{W} / \mathrm{cm}^{2}$, wavelength: 400-800 $\mathrm{nm}$ ) with a visual light module and an optical filter (cutoff $<400 \mathrm{~nm}$ ). The time-dependent photobleaching was monitored by measuring the UV-vis absorbance at $785 \mathrm{~nm}$ (Figure S8). UV-vis absorption spectra in nearinfrared region are summarized in Figure S8a. The photostability of CypH3-SAc was better than that of ICG. In the case of CypH3, the absorbance of СypH3-O increased during the initial 30 min irradiation, probably because 
of the photo-induced ring-opening of CypH3-C. Similar photo-induced ring-opening was reported by Raymo et al. ${ }^{9}$
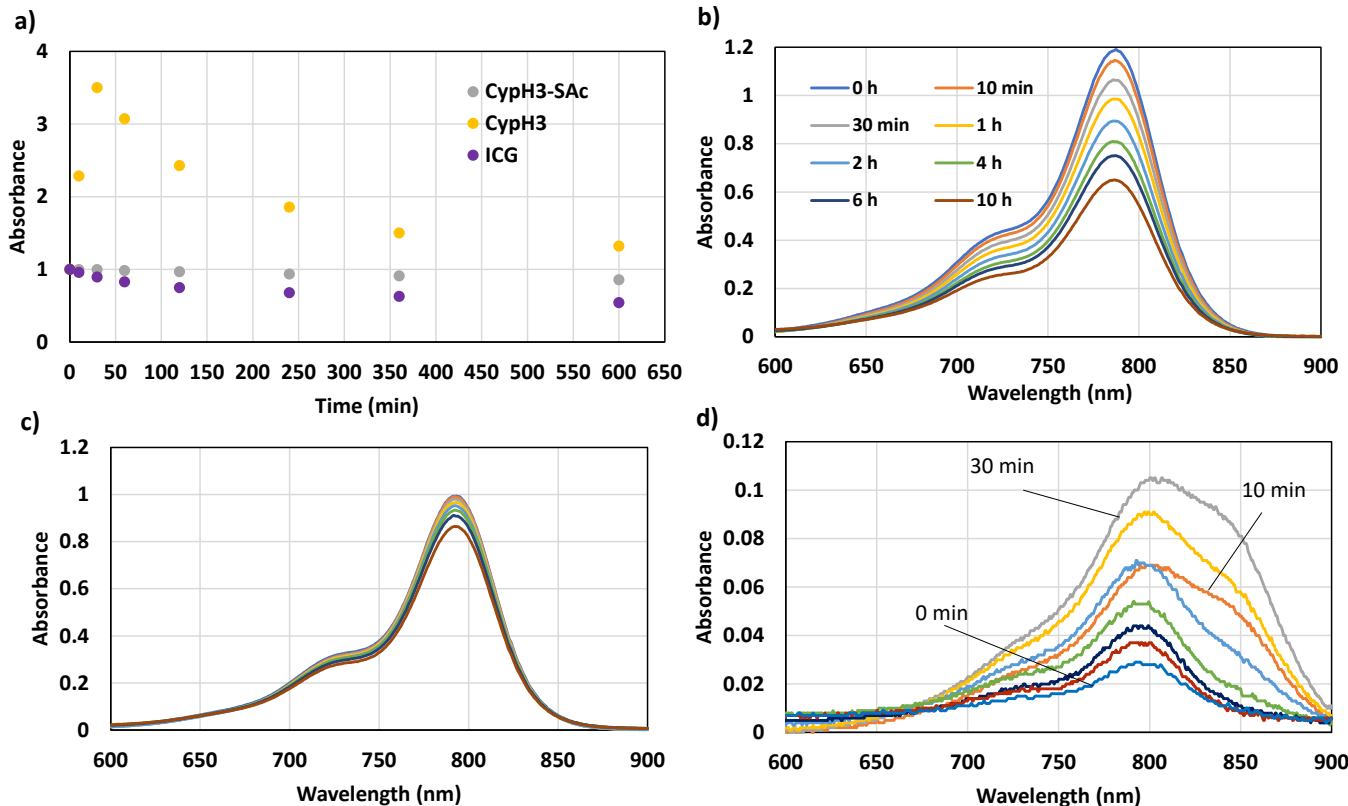

Figure S8. (a) Time-dependent change of absorbance at $785 \mathrm{~nm}$ of CypH3-SAc (gray), CypH3 (yellow), indocyanine green (ICG, purple) in EtOH after continuous photoirradiation $\left(20 \mu \mathrm{W} \cdot \mathrm{cm}^{-2}\right.$, visible light). Timedependent change of absorbance spectra of (b) ICG, (c) CypH3-SAc, and (d) CypH3 in EtOH. Absorbance spectra were measured before and after 10, 30, 60, 120, 360, and 600 min irradiation.

\subsection{UV-vis absorption and fluorescence spectra of pH-responsive dyes Cy-SAc-RGD}
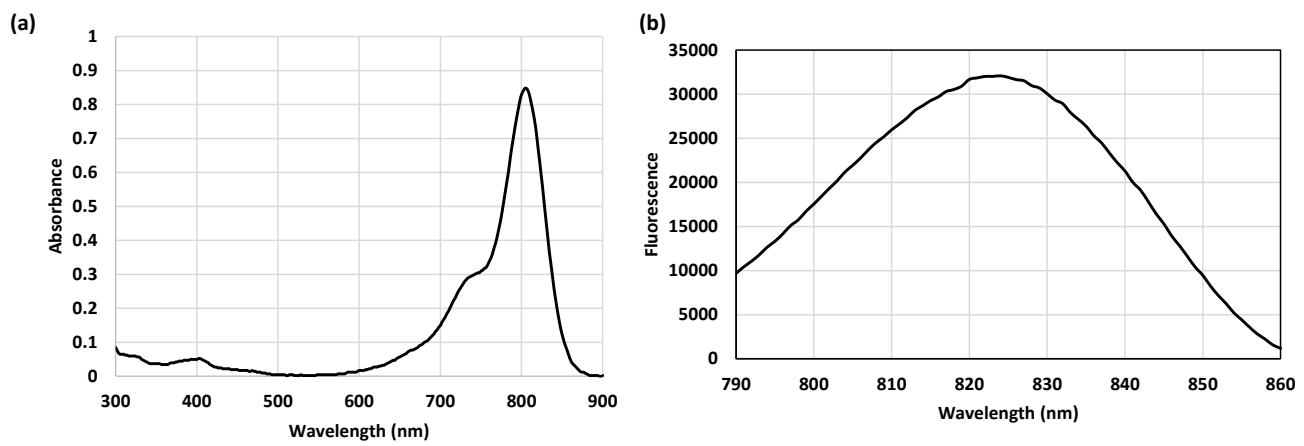

Figure S9. (a) UV-vis absorption and (b) fluorescence spectra of Cy-SAc-RGD in PBS buffered solution (0.1 $\mathrm{M}, \mathrm{pH} 7.2)$ with Triton $\mathrm{X}-100\left(2 \times 10^{-3} \mathrm{M}\right)$.

\subsection{Cytotoxicity experiments}

\section{MTT assay}

Measurement of cell viability was evaluated by reducing of MTT (3-(4,5-dimethyl-2-thiazolyl)-2,5- 
diphenyltetrazolium bromide) to formazan crystals using mitochondrial dehydrogenases. The cytotoxicity assays were performed by A549 cells in 96-well plates with a seeding density of $1 \times 10^{4}$ cells per well. After 24 $\mathrm{h}$ of cell attachment at $37{ }^{\circ} \mathrm{C}$ in $5 \% \mathrm{CO}_{2}$ before adding test substances, the plate was washed with $100 \mu \mathrm{L} /$ well PBS. Then the cells were cultured in medium with $0.01,0.1,1,10,100 \mu \mathrm{M}$ of probe CypHRGD under $4{ }^{\circ} \mathrm{C}$ or $37{ }^{\circ} \mathrm{C}$ for $12 \mathrm{~h}$. Cells in culture medium without probe were used as the control. Six replicate wells were used for each control and test concentration. $100 \mu \mathrm{L}$ of MTT $(0.5 \mathrm{mg} / \mathrm{mL})$ prepared in medium was added to each well and the plates were incubated at $37{ }^{\circ} \mathrm{C}$ for another $4 \mathrm{~h}$ in a $5 \% \mathrm{CO}_{2}$ humidified incubator. Wells without cell were used as the blank. The medium was carefully removed and washed with PBS, and the purple crystals were lysed in $200 \mu \mathrm{L}$ DMSO. Absorbance at $550 \mathrm{~nm}$ was measured with micro-plate spectrophotometer (800TS, Biotek Instruments, Inc. USA). Cell viability was calculated using the following equation:

$$
\text { Cell viability }(\%)=\left(\mathrm{A}_{\text {test }}-\mathrm{A}_{\text {blank }}\right) /\left(\mathrm{A}_{\text {control}}-\mathrm{A}_{\text {blank }}\right) \times 100
$$
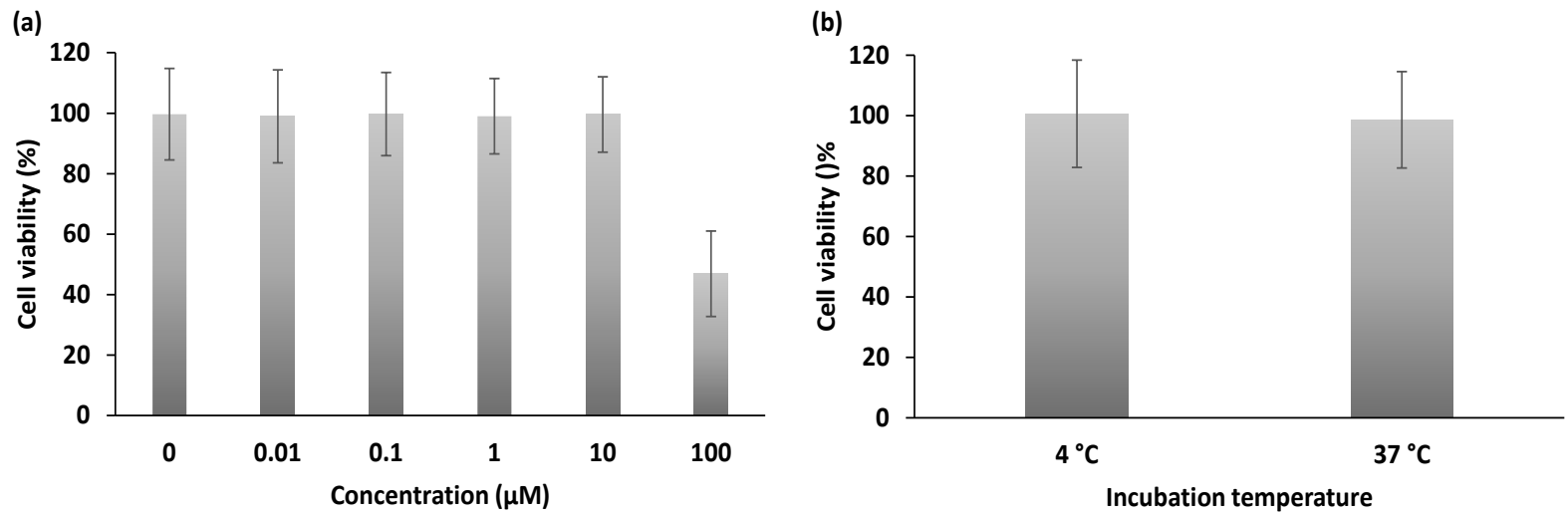

Figure S10. (a) Cytotoxicity of CypHRGD in varied concentration $(0,0.01,0.11,10,100 \mu \mathrm{M})$ in living A549 cells for $12 \mathrm{~h}$. (b) Cytotoxicity of CypHRGD $(10 \mu \mathrm{M})$ in living A549 cells incubated under $4{ }^{\circ} \mathrm{C}$ or $37^{\circ} \mathrm{C}$ for 4 h. Error bar indicates s.d., $n=6$.

\section{Measurement of cell confluence after incubation of probe CypHRGD}

After $24 \mathrm{~h}$ of cell attachment at $37^{\circ} \mathrm{C}$ in $5 \% \mathrm{CO}_{2}$ before adding test substances, A549 cells $\left(4 \times 10^{5}\right.$ cells/well in 12-well plate) were cultured in medium with 0,1 or $10 \mu \mathrm{M}$ of probe CypHRGD under $37^{\circ} \mathrm{C}$ for $12 \mathrm{~h}$. Cells in culture medium without probe were used as the control. Wells without probe were used as the blank. Six replicate wells were used for each control and test concentration. Then the plate was washed with $100 \mu \mathrm{L} /$ well PBS. The cells were treated with $1 \mathrm{mmol} / \mathrm{L}$ EDTA-0.25\% Trypsin solution $(100 \mu \mathrm{L} /$ well $)$ to dissociate from the dishes. The cell confluence was then examined by counting cells of each dish after staining with $0.4 \%$ Trypan Blue solution. Cell viability was calculated using the following equation $\left(\mathrm{N}_{\text {test }}\right.$ : cell number in test dishes; $\mathrm{N}_{\text {blank: }}$ : cell number in control dishes):

$$
\text { Cell viability }(\%)=\left(\text { average } \mathrm{N}_{\text {test }}\right) /\left(\text { average } \mathrm{N}_{\text {blank }}\right) \times 100
$$




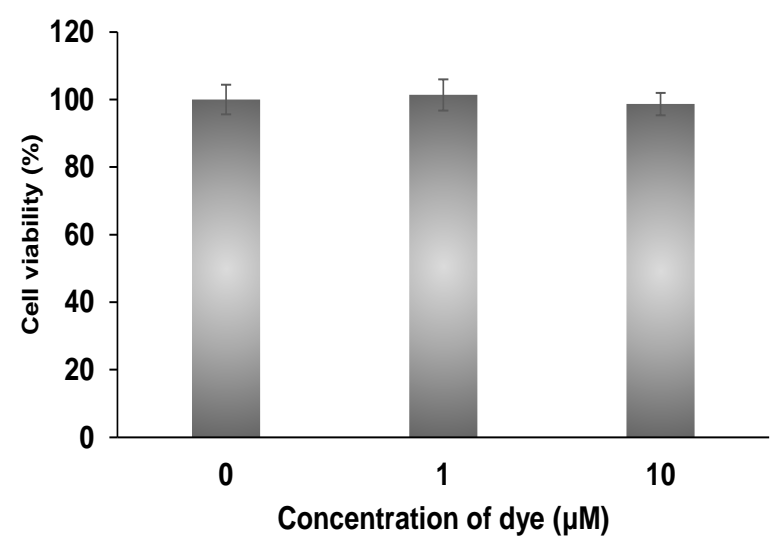

Figure S11. Cytotoxicity of CypHRGD in varied concentration $(0,1$, and $10 \mu \mathrm{M})$ in living A549 cells for $12 \mathrm{~h}$ by examined the cell confluence. Error bar indicates s.d., $\mathrm{n}=6$.

\subsection{In vitro cell imaging experiment: cell internalization}

Human lung carcinoma cell line, A549, was purchased from American Type Culture Collection (Manassas, VA). Normal cell line, Swiss mouse embryo fibroblast NIH-3T3, were purchased from Japanese Collection of Research Bioresources Cell Bank (JCRB cell bank), Japan. A549 cells and NIH-3T3 cells were cultured in 10\% FBS-Dulbecco's modified Eagle's medium (DMEM). Cells were cultured in well-humidified incubator with 5\% $\mathrm{CO}_{2}$ and $95 \%$ air at $37^{\circ} \mathrm{C}$.

\section{IVIS imaging}

We prepared two 12-well cell-culture plates for each in vitro experiment. A549 cells $\left(4 \times 10^{5}\right.$ cells/well in 12 well plate) were cultured with ICG, CypHRGD $\left(1.0 \times 10^{-5} \mathrm{M}, 0.5 \mathrm{~mL}\right)$, CypHRGD with cRGD (10 eq.) in DMEM without phenol red for $4 \mathrm{~h}$. During $4 \mathrm{~h}$ incubation, one of plate was placed on ice $\left(4^{\circ} \mathrm{C}\right)$, and another was placed on a hot plate $\left(37^{\circ} \mathrm{C}\right)$. Every $1 \mathrm{~h}$, the fluorescence intensities of cells were measured by optical imaging device IVIS-lumina (ICG filter $\lambda_{\mathrm{ex}}=745 \mathrm{~nm}, \lambda_{\mathrm{em}}=820 \mathrm{~nm}$, PerkinElmer Inc., USA). After $4 \mathrm{~h}$ incubation, cells were washed with phosphate buffer saline $(1 \mathrm{~mL} \times 2)$ and the wells were refilled by $10 \%$ FBSDMEM $(1 \mathrm{~mL})$. NIH-3T3 cells were incubated with CypHRGD $\left(1.0 \times 10^{-5} \mathrm{M}\right)$ under the same condition with A549 cells. Fluorescence intensities (photons per second) from cells were measured by IVIS imaging device. Images were analyzed using Living Image 2.50-Igor Pro 4.09 software (PerkinElmer Inc., USA.), according to the manufacturer's instructions. The fluorescence dyes in the same batch were injected to three wells and one set of experiment was repeated twice to confirm reproducibility, and representative images are shown (Figure S12-S14, and S16).

\section{Confocal imaging}

A549 cells were passaged to $\mu-35 \mathrm{~mm}$ dish in a concentration of $2 \times 10^{5}$ cells/dish for confocal imaging. Cells 
were treated with CypHRGD $(10 \mu \mathrm{M})$ for $4 \mathrm{~h}$ at $37{ }^{\circ} \mathrm{C}$ and wash with DMEM, then treated with LysoTracker green DND-26 (50 nM) for $15 \mathrm{~min}$, and the images was acquired by confocal microscopy (LSM710, Figure S15). Green channel: 490-590 nm; Red channel: 638-758 nm. The images were acquired with simultaneous excitation by $488 \mathrm{~nm}$ and $633 \mathrm{~nm}$ lasers in a frame scan mode.

\section{PA imaging}

We also prepared two 12-well cell-culture plates for each in vitro photoacoustic experiment. A549 cells $(4 \times$ $10^{5}$ cells/well in 12-well plate) were cultured with ICG, CypHRGD $\left(1.0 \times 10^{-5} \mathrm{M}, 0.5 \mathrm{~mL}\right)$, or CypHRGD with cRGD (10 eq.) in DMEM without phenol red for 0 or $4 \mathrm{~h}$. During $4 \mathrm{~h}$ incubation, one of plate was placed on ice $\left(4{ }^{\circ} \mathrm{C}\right)$, and another was placed on a hot plate $\left(37^{\circ} \mathrm{C}\right)$. After $4 \mathrm{~h}$ incubation, cells were washed with phosphate buffer saline $(1 \mathrm{~mL} \times 2)$ and the wells were refilled by $10 \%$ FBS-DMEM $(1 \mathrm{~mL})$. Then the cells were collected by cell scrapper and the cell suspension solution was transferred to $1.5 \mathrm{~mL}$ tube. The PA signals of cells were measured and quantified by Nexus 128 instrument. The dyes in the same batch were injected to three wells and one set of experiment was repeated twice to confirm reproducibility, and representative images are shown (Figures S13 and S16).

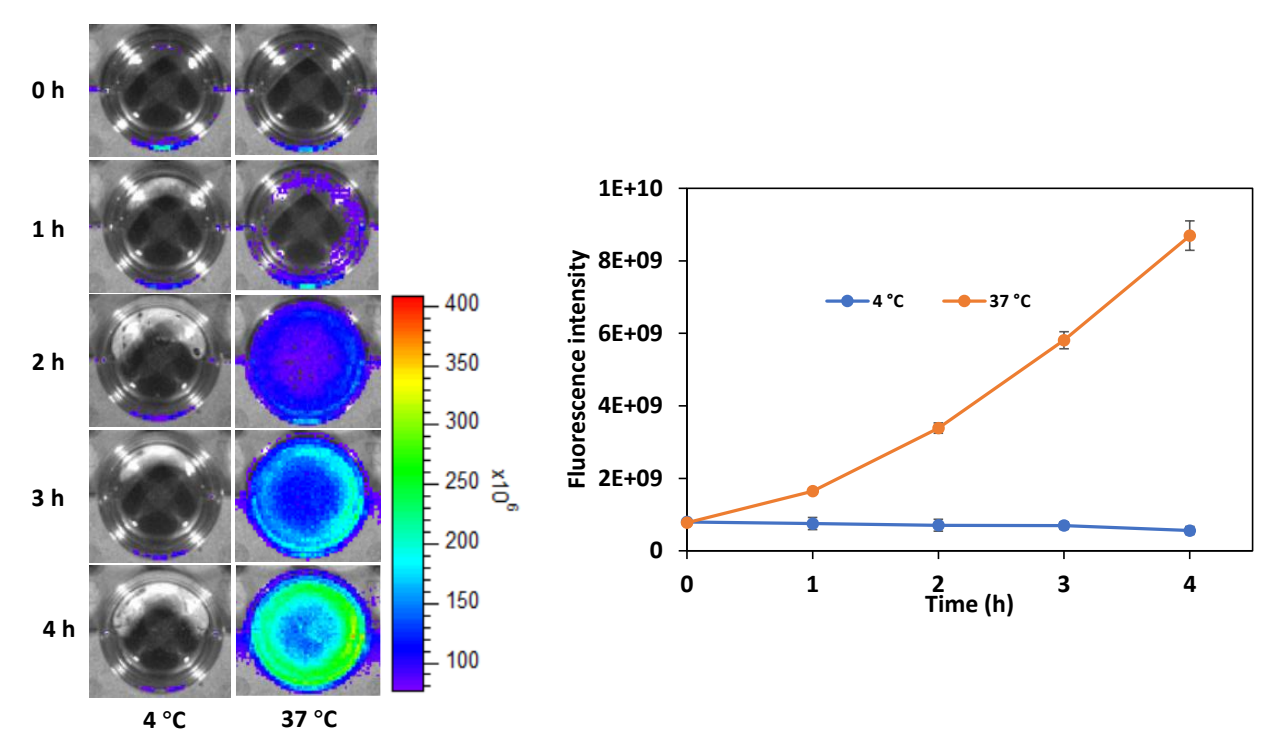

Figure S12. Time-dependent optical imaging (left) and quantified fluorescence intensity (right) of A549 cells incubated in DMEM solutions $(2 \mathrm{~mL})$ with CypHRGD $\left(1.0 \times 10^{-5} \mathrm{M}\right)$ at $4{ }^{\circ} \mathrm{C}$ (blue) and $37^{\circ} \mathrm{C}$ (orange). Error bar indicates s.d., $\mathrm{n}=3$. 


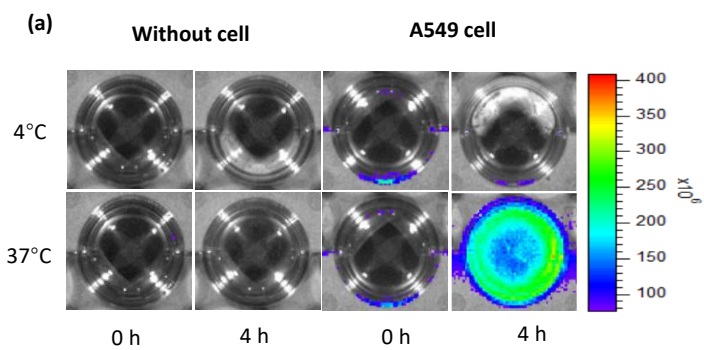

(c)

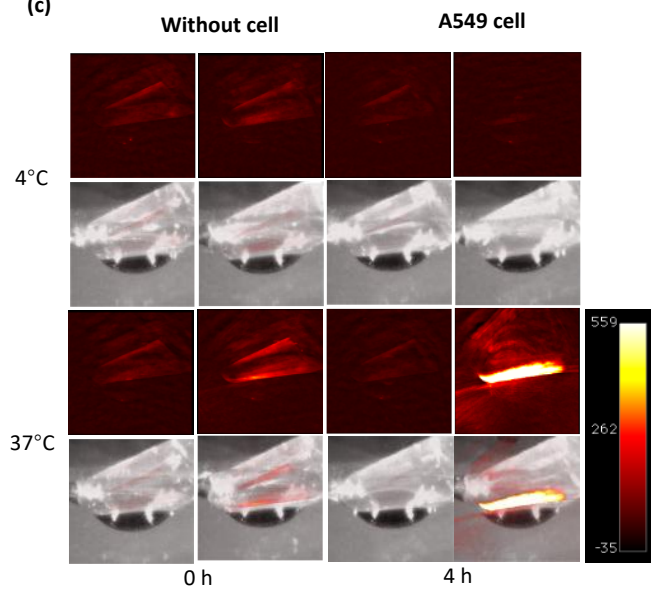

(b)
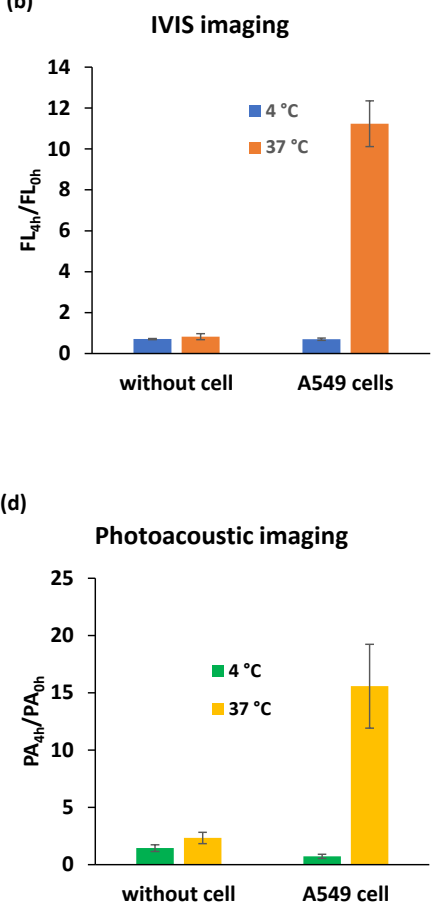

Figure S13. (a) Representative optical images and (b) fluorescence quantification of dishes with or without A549 cells after incubation for 0 and $4 \mathrm{~h}$ with CypHRGD $(10 \mu \mathrm{M})$ at $4{ }^{\circ} \mathrm{C}$ or $37^{\circ} \mathrm{C}$. (c) Representative photoacoustic (PA) images and (d) PA intensity quantification of tubes containing A549 cells collected by cell scrapper from the dishes after incubation for 0 and $4 \mathrm{~h}$ with CypHRGD $(10 \mu \mathrm{M})$ at $4{ }^{\circ} \mathrm{C}$ or $37^{\circ} \mathrm{C}$. Error bar indicates s.d., $\mathrm{n}=$ 3.

(a)

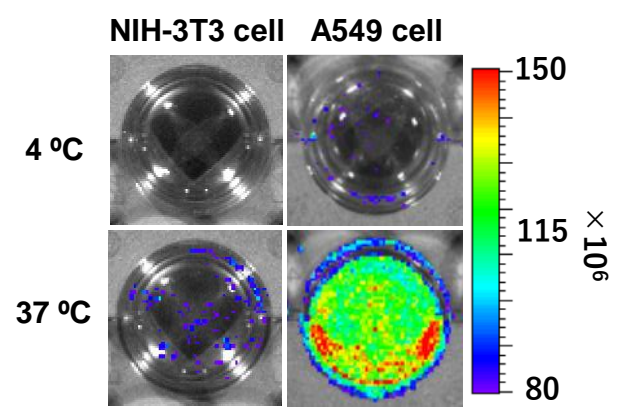

(b)

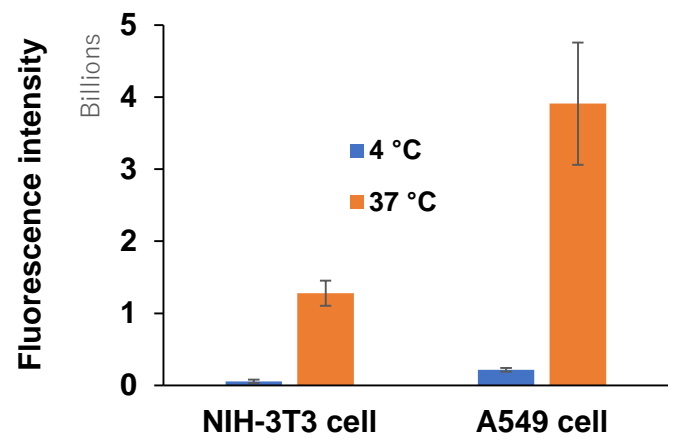

Figure S14. (a) Representative optical images and (b) fluorescence quantification of dishes with NIH-3T3 cells (normal cell) and A549 cells (cancer cell) after incubation for 0 and $4 \mathrm{~h}$ with CypHRGD $(10 \mu \mathrm{M})$ at $4{ }^{\circ} \mathrm{C}$ or $37^{\circ} \mathrm{C}$, followed with washing procedure. Error bar indicates s.d., $\mathrm{n}=3$. 


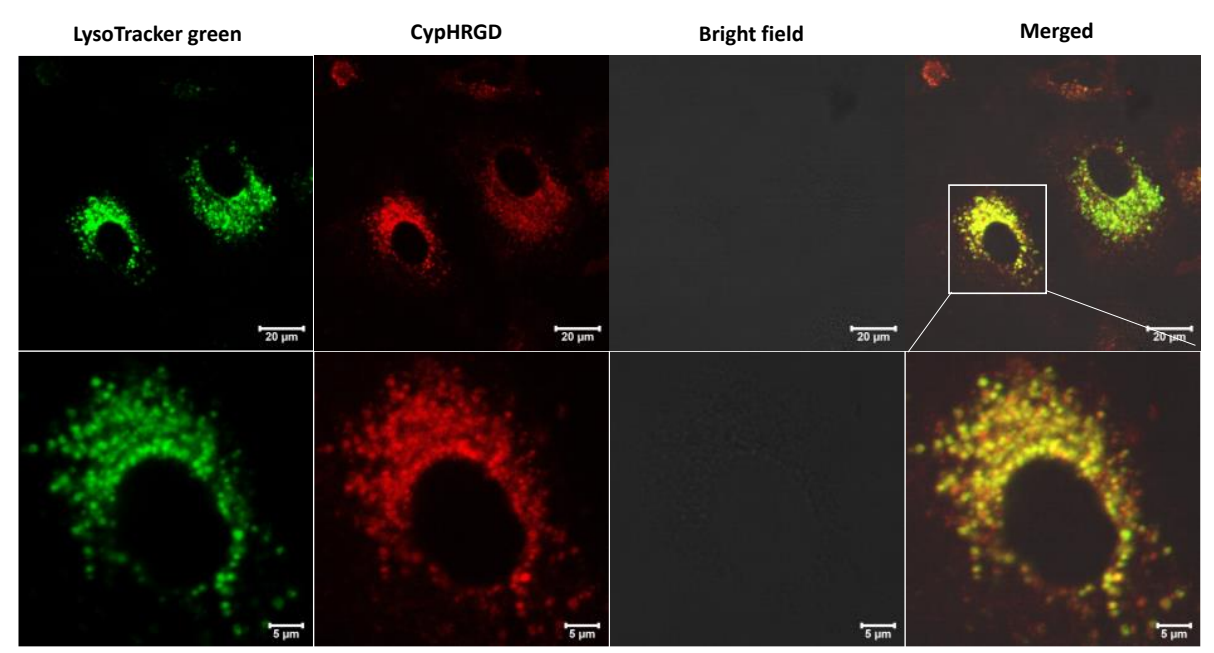

Figure S15. Lysosomal accumulation with living A549 cells after incubation with CypHRGD for $4 \mathrm{~h}$. Colocalization of CypHRGD ( $5 \mu \mathrm{M}$, red channel) overlapped with LysoTracker (50 nM, green channel) is in yellow in the merged images.
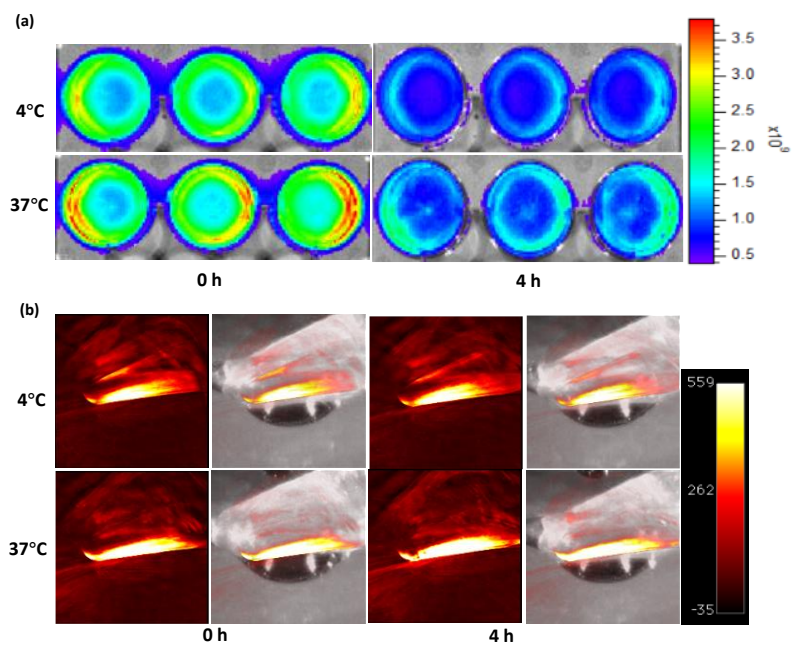

Figure S16. (a) Optical and (b) PA imaging of A549 cells incubated in DMEM solutions (2 mL) with ICG (1.0 $\times 10^{-5} \mathrm{M}$ ) for $0 \mathrm{~h}$ and $4 \mathrm{~h}$ at $4{ }^{\circ} \mathrm{C}$ and $37^{\circ} \mathrm{C}$.

\subsection{In vivo experiments}

Female BALB/c mice, 6-9 weeks of age were chosen to prepare the tumor-bearing mice by injection of A549 cells $\left(5 \times 10^{6}\right.$ cells) in the right leg of each mouse. The tumor size was carefully monitored and conducted in the Radiation Biology Center, Kyoto University. Then tumor-bearing mice were treated with CypH3, CypHRGD, and CyRGD (100 $\mu \mathrm{M}$ in $200 \mu \mathrm{L}$ saline) through intravenous injection. Then the IVIS fluorescence images equipped with ICG filter $\left(\lambda_{\mathrm{ex}}=745 \mathrm{~nm}, \lambda_{\mathrm{em}}=820 \mathrm{~nm}\right)$ were recorded before and post-injection at different time points $(1,3,6,9$, and $24 \mathrm{~h})$. Twenty-four hours after administration, the mice were sacrificed and dissected of 
the tumors and organs for ex vivo imaging. Fluorescence intensities (photons per second) were quantified by Living Image 2.50-Igor Pro 4.09 software. The fluorescence intensities of regions of interest (ROI: muscle or tumor sites) were detected from each mouse in the same size (diameter of circle $=1.02 \mathrm{~cm}$ ). Simultaneously, PA images were measured at $797 \mathrm{~nm}$ and $850 \mathrm{~nm}$ (hemoglobin) at indicated time points and the normalized PA was obtained by the subtraction of $\mathrm{PA}_{850 \mathrm{~nm}}$ with $\mathrm{PA}_{797 \mathrm{~nm}}$. For each probe, three mice were conducted for this study to confirm the reproducibility. The represent intensities were calculated in the mean of independent experiments ( $\mathrm{n}$ 3) with standard deviation (s.d.).
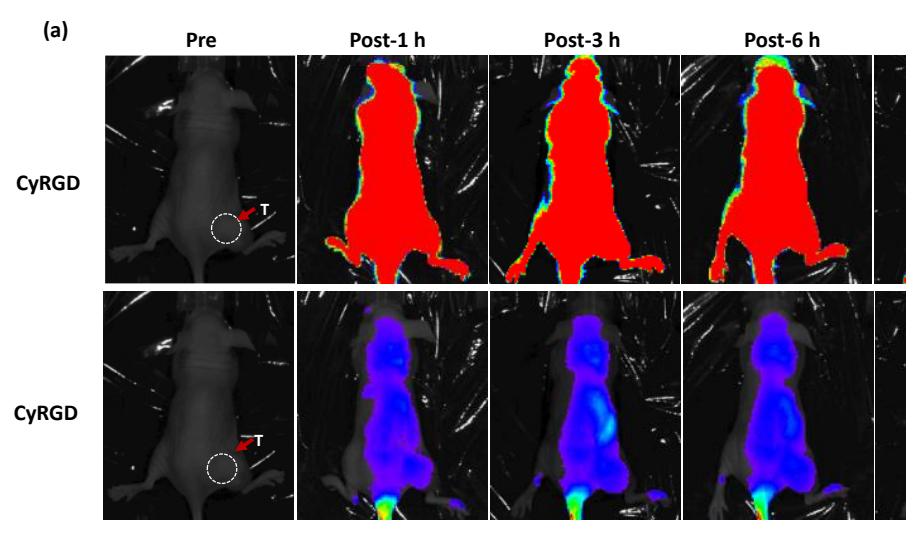

Post-9 h

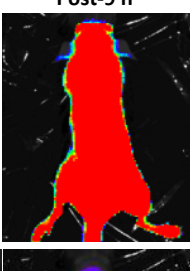

Post-24 h
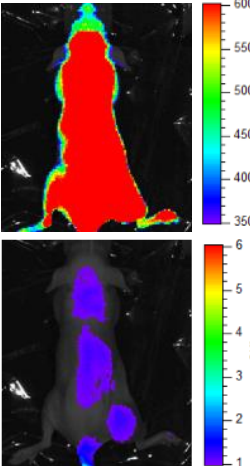

(b)
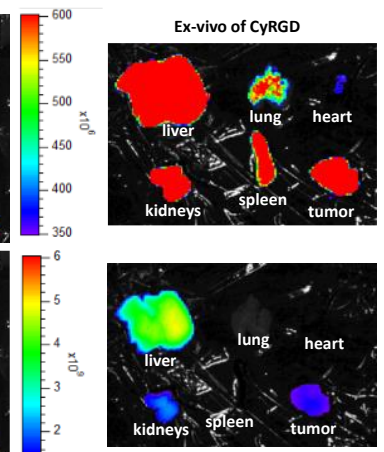

Figure S17. (a) In vivo and (b) ex vivo NIRF imaging of tumor bearing mice by using control molecule CyRGD (100 $\mu \mathrm{M}$ in $200 \mu \mathrm{L}$ saline) post-injection time point $(0,1,3,6,9$, and $24 \mathrm{~h})$ under different ratio bar.

\section{References}

(1) Miki, K.; Enomoto, A., Inoue, T.; Nabeshima, T.; Saino, S.; Shimizu, S.; Matsuka, H.; Ohe, K., Polymeric self-assemblies with boron-containing near-infrared dye dimers for photoacoustic imaging probes. Biomacromolecules 2017, 18, 249-256.

(2) Miki, K.; Inoue, T.; Kobayashi, Y.; Nakano, K.; Matsuoka, H.; Yamauchi, F.; Yano, T.; Ohe, K., Nearinfrared dye-conjugated amphiphilic hyaluronic acid derivatives as a dual contrast agent for in vivo optical and photoacoustic tumor imaging. Biomacromolecules 2015, 16, 219-227.

(3) Miki, K.; Kojima, K.; Oride, K.; Harada, H.; Morinibu, A.; Ohe, K., pH-Responsive near-infrared fluorescent cyanine dyes for molecular imaging based on pH sensing. Chem. Commun. 2017, 53, 77927795 .

(4) Akimoto, R.; Tokugawa, T.; Yamamoto, Y.; Yamataka, H., Reaction pathway and rate-determining step of the Schmidt rearrangement/fragmentation: a kinetic study. J. Org. Chem. 2012, 77, 4073-4078.

(5) He, C.; Guo, S.; Huang, L.; Lei, A., Copper catalyzed arylation/C-C bond activation: an approach toward a-aryl ketones. J. Am. Chem. Soc. 2010, 132, 8273-8275. 
(6) Zhu, J.; Marchant, R. E., Solid-phase synthesis of tailed cyclic RGD peptides using glutamic acid: unexpected glutarimide formation. J. Pept. Sci. 2008, 14, 690-696.

(7) Becke, A. D., Density-functional thermochemistry. III. The role of exact exchange. J. Chem. Phys. 1993, $98,5648-5652$.

(8) Zhao, Y.; Truhlar, D. G., The M06 suite of density functionals for main group thermochemistry, thermochemical kinetics, noncovalent interactions, excited states, and transition elements: two new functionals and systematic testing of four M06-class functionals and 12 other functionals. Theor. Chem. Acc. 2008, 120, 215-241.

(9) Swaminathan, S.; Garcia-Amorios, J.; Fraix, A.; Kandoth, N.; Sortino, S.; Raymo, F. M., Photoresponsive polymer nanocarriers with multifunctional cargo. Chem. Soc. Rev. 2014, 43, 41674178.

\title{
<Cartesian coordinates for optimized geometry of CypH1-O and CypH3-O derivatives>
}

\author{
CypH1-O derivative optimized at the B3LYP/6- \\ 31G(d) level \\ $\mathrm{C}, 0,-8.0328118581,3.2620994409,-0.4035098116$ \\ C, $, 0,-7.0122742544,4.1355601047,-0.106472509$ \\ $\mathrm{C}, 0,-5.6798088001,3.6748324925,0.0616113451$ \\ $\mathrm{C}, 0,-5.3970089961,2.2690017249,-0.0847866224$ \\ C, $0,-6.4796747486,1.3967908487,-0.3915224967$ \\ C, $0,-7.7593778924,1.8812785459,-0.5457093246$ \\ C, $0,-4.6299334124,4.5826894117,0.3683623232$ \\ C, $0,-3.3306785539,4.1611975006,0.5365397213$ \\ C, $0,-3.0733776931,2.7824466206,0.3928533935$ \\ C, $0,-4.0497908008,1.8537603176,0.0888271883$ \\ $\mathrm{N}, 0,-1.8165280495,2.1373512799,0.5351576835$ \\ C, $0,-1.9251488264,0.8068767703,0.2966819612$ \\ C, $0,-3.4016128999,0.4787840915,0.0112117837$ \\ C, $0,-3.5292201251,-0.1533772791,-1.3971441133$ \\ C, $0,-3.9408514337,-0.4797877478,1.1040713727$
}

C, $0,-0.9425827441,-0.1840220556,0.2887814119$
C, $0,0.4557002989,-0.0978423385,0.2964195109$
C, $0,1.3001008212,-1.2074887922,0.2713092938$
C, $0,2.6908400562,-1.1022260869,0.213415908$
C, $0,3.5805103178,-2.1777331728,0.1749368203$
C, $0,4.9627475585,-2.0154608989,0.1033840417$
C, $0,5.8762607397,-3.0757410129,0.0544231832$
C, $0,7.2655000299,-2.9877430716,-0.0224946615$
C, $0,-0.627883784,2.8621068449,0.9816124841$
C, $0,0.1673114495,3.4986477501,-0.1703479333$
C,0,1.3840168218,4.266401206,0.3544892886
S,0,2.3617894885,4.8934499976,-1.0781897092
N,0,8.0515087886,-4.0929100631,-0.0723170131
C, $0,9.4226956684,-3.7512777903,-0.1367362529$
C, $0,9.556997427,-2.3747312425,-0.1374217593$
C, $0,8.1679125614,-1.7438822222,-0.0656840772$
C, $0,7.8678625689,-0.9102349977,-1.3385503534$
C,0,7.9977775659,-0.913950038,1.2328817365 
C,0,7.5418126374,-5.4579853749,-0.0615956033 C, $0,10.5193018432,-4.6357869073,-0.1920949856$ C, $0,11.7770292407,-4.0823175898,-0.2511918534$ C, $0,11.9798878996,-2.6754532233,-0.2576288481$ C, $0,10.8483277448,-1.7845198793,-0.1997040367$ C, $0,13.290176775,-2.132682029,-0.3204968314$ C, $0,13.4957318315,-0.7723831034,-0.3276537386$ C, $0,12.3884231919,0.1058933556,-0.2718321684$ C, $0,11.1026232219,-0.3832461885,-0.2096204131$ $\mathrm{H}, 0,-9.0475895709,3.627397725,-0.5289880481$ $\mathrm{H}, 0,-7.2125739966,5.19808064,0.0053801427$ $\mathrm{H}, 0,-6.3005278637,0.334186437,-0.5069662489$ $\mathrm{H}, 0,-8.5688449325,1.1958076608,-0.77975824$ $\mathrm{H}, 0,-4.8699793447,5.6376434031,0.4674907645$ $\mathrm{H}, 0,-2.5441142519,4.8732747356,0.7607085981$ H, $0,-2.9849158614,-1.1015299129,-1.4480074306$ $\mathrm{H}, 0,-4.5768462262,-0.3516166202,-1.6371318264$ $\mathrm{H}, 0,-3.1279367103,0.5151518064,-2.1649180146$ H, $0,-5.0056106451,-0.672916188,0.9509376305$ $\mathrm{H}, 0,-3.4172742712,-1.44072113,1.0747120577$ $\mathrm{H}, 0,-3.8168128511,-0.0484230633,2.102055879$ $\mathrm{H}, 0,-1.3434114213,-1.1909536544,0.2045741232$ $\mathrm{H}, 0,0.9416414199,0.8733379135,0.2752510911$ $\mathrm{H}, 0,0.8547566121,-2.2014681254,0.2888725386$ $\mathrm{H}, 0,3.1179015374,-0.0979269344,0.1907028886$ $\mathrm{H}, 0,3.1741136143,-3.1883228854,0.1960459349$ H, $0,5.332487902,-0.9940544414,0.0820206498$ $\mathrm{H}, 0,5.4467251575,-4.0736351728,0.0791419532$ $\mathrm{H}, 0,-0.9645111814,3.6346274418,1.6799219195$ $\mathrm{H}, 0,-0.0108982712,2.1679298773,1.557857069$ $\mathrm{H}, 0,0.4876207589,2.7192467105,-0.8721958007$ $\mathrm{H}, 0,-0.4849943669,4.1755151479,-0.7334976566$ $\mathrm{H}, 0,1.0633069088,5.1106068375,0.9728868801$ $\mathrm{H}, 0,2.0144060407,3.6139641673,0.9687949058$ H,0,3.2459043367,5.6170152754,-0.3590953344 $\mathrm{H}, 0,8.5718359475,-0.0793696834,-1.4256899587$ $\mathrm{H}, 0,6.8562333356,-0.496490376,-1.3191253847$ $\mathrm{H}, 0,7.9657554229,-1.5266436808,-2.2373226357$ $\mathrm{H}, 0,8.1952726482,-1.5302472139,2.1152417687$ $\mathrm{H}, 0,8.6993091339,-0.0765722222,1.2467886569$ H,0,6.9859801028,-0.5097184596,1.320698845 H,0,6.8587109562,-5.6146630944,-0.9024672723 $\mathrm{H}, 0,8.3703486029,-6.1569364622,-0.1539361601$ H, $0,7.0119551233,-5.6628551925,0.8745675466$ $\mathrm{H}, 0,10.3940814739,-5.7127254531,-0.1871164205$ H,0,12.6474881293,-4.7310165674,-0.2941958793
$\mathrm{H}, 0,14.1337885267,-2.8168617348,-0.3633974525$ $\mathrm{H}, 0,14.5030788611,-0.3701283088,-0.3762942251$ $\mathrm{H}, 0,12.554707044,1.179346572,-0.2785882216$ $\mathrm{H}, 0,10.2761504939,0.3162790281,-0.169224968$

\section{CypH3-O derivative optimized at the B3LYP/6- 31G(d) level}

C, $0,-8.0533146082,3.2159726246,0.1753336726$

C, $0,-7.0247763989,4.093350031,-0.079392186$

C, $0,-5.6909977239,3.6323268953,-0.2366557708$

C, $0,-5.4154459547,2.2219971653,-0.1243537806$

C, $0,-6.5062182524,1.3459324728,0.1398221492$

C,0,-7.7868656406,1.8307796064,0.2846833899

C, $0,-4.6327551488,4.5440834177,-0.4994975973$

C, $0,-3.3322144356,4.122144074,-0.6569341661$

C, $0,-3.082026166,2.7387980968,-0.5482042348$

C, $0,-4.0670472121,1.8061539721,-0.286850605$

$\mathrm{N}, 0,-1.8255870763,2.0927682195,-0.6881404604$

C, $0,-1.9435710705,0.7558037657,-0.4903225633$

C, $0,-3.4258444541,0.4265385114,-0.2375831312$

C, $0,-3.9516369073,-0.4984900222,-1.3653420197$

C, $0,-3.5786379209,-0.2440494904,1.1502480969$

C, $0,-0.9667890198,-0.239541484,-0.4984815716$

C, $0,0.4328756594,-0.1635806494,-0.4875607621$

C, $0,1.2664605983,-1.2807903551,-0.4942026125$

C, $0,2.6580528425,-1.1934494265,-0.4169156646$

C, $0,3.5338022397,-2.2805199068,-0.4126447816$

C, $0,4.9164686317,-2.1361034082,-0.3180507262$

C, $0,5.8172551254,-3.2073108039,-0.2824734428$

C, $0,7.2034440676,-3.1042662559,-0.2049607518$

C, $0,-0.6273860299,2.8236491992,-1.0964550172$

C, $0,0.1516216781,3.4276224676,0.0836685055$

C, $0,1.3740455189,4.2109756548,-0.40373939$

S, $0,2.320265722,4.8229802627,1.0567523835$

$\mathrm{N}, 0,8.0116170833,-4.1893664201,-0.1057096839$

C, $0,9.3753349656,-3.8152329312,-0.0358670646$

C, $0,9.4794911056,-2.4381019273,-0.0875616363$

C, $0,8.0843670182,-1.8405875225,-0.2793397116$

C, $0,7.5269675622,-5.5624740352,-0.0558503526$

C, $0,10.4942157724,-4.6673450945,0.0666608918$

C, $0,11.7372280057,-4.0785102302,0.1172544234$

C, $0,11.9040481966,-2.6671194811,0.0752581768$

C, $0,10.7501696668,-1.8109327494,-0.0254573241$

C, $0,13.1958353904,-2.0809969445,0.1302366592$ 
C, $0,13.3556342857,-0.7147598976,0.0913200496$ C, $0,12.2215738385,0.1274296689,0.0034874113$ C, $0,10.951897052,-0.4027600019,-0.0517155603$ C, $0,7.9788007734,-1.2850338157,-1.7266433117$ C, $0,7.7195453377,-0.8211382767,0.8149959351$ C, $0,7.782869947,-1.2156999335,2.1598833185$ C, $0,7.4643497114,-0.3262912259,3.1833361488$ C,0,7.0779676929,0.9821192258,2.8822120151 C, $0,7.0163784177,1.3881860164,1.5507747052$ C, $0,7.33472262,0.4935084745,0.5240808531$ $\mathrm{H}, 0,-9.0689823994,3.5814869898,0.2928090905$ H,0,-7.2194945517,5.1593239193,-0.1654348784 $\mathrm{H}, 0,-6.3324656434,0.2799728765,0.2296332885$ $\mathrm{H}, 0,-8.6025169257,1.14222557,0.4859721354$ $\mathrm{H}, 0,-4.8672040733,5.6023924056,-0.5729996359$ $\mathrm{H}, 0,-2.5395205842,4.8374083876,-0.8469799958$ $\mathrm{H}, 0,-3.4325532011,-1.4622848738,-1.3551233332$ $\mathrm{H}, 0,-5.0195291089,-0.6909593143,-1.2348934629$ $\mathrm{H}, 0,-3.8097926255,-0.0398297987,-2.3486869687$ $\mathrm{H}, 0,-4.6303998914,-0.4482816498,1.3662030074$ H, $,-3.0350317468,-1.1933464363,1.1848757275$ $\mathrm{H}, 0,-3.1911461337,0.4029766751,1.9431447769$ $\mathrm{H}, 0,-1.3742033991,-1.2462505091,-0.4504702739$ $\mathrm{H}, 0,0.9263821042,0.802275879,-0.4258953899$ $\mathrm{H}, 0,0.8115311602,-2.2688062729,-0.5544939715$ H,0,3.0973231516,-0.1967620263,-0.347913674 H,0,3.1152668951,-3.2843348632,-0.4789183746
$\mathrm{H}, 0,5.3063711348,-1.1241882304,-0.2425568015$ H, 0,5.389778786,-4.2062830207,-0.3072818312 $\mathrm{H}, 0,-0.0035532375,2.1422878114,-1.6805387057$ $\mathrm{H}, 0,-0.9498659584,3.6153965291,-1.7798440153$ $\mathrm{H}, 0,-0.5084561976,4.088775365,0.6563755212$ $\mathrm{H}, 0,0.4630377021,2.6287021648,0.7673899117$ $\mathrm{H}, 0,2.021016571,3.5731645871,-1.0159598328$ $\mathrm{H}, 0,1.0599032114,5.0635074039,-1.014157748$ $\mathrm{H}, 0,3.1956125666,5.584731155,0.3667937156$ $\mathrm{H}, 0,6.8345104054,-5.6901134626,0.7822844084$ H, $0,7.0140323175,-5.8230418379,-0.9876949455$ $\mathrm{H}, 0,8.367075689,-6.2403057396,0.0813621553$ $\mathrm{H}, 0,10.3968097345,-5.7467864269,0.1001449911$ $\mathrm{H}, 0,12.6233356698,-4.7027078979,0.1923733035$ $\mathrm{H}, 0,14.0612328059,-2.7345838573,0.2047252599$ $\mathrm{H}, 0,14.3493195349,-0.278924249,0.1336238972$ $\mathrm{H}, 0,12.3554660615,1.2053222146,-0.014503326$ $\mathrm{H}, 0,10.094190129,0.2588230905,-0.0937654506$ $\mathrm{H}, 0,8.6819665886,-0.4615146341,-1.8746368599$ H, $0,6.9668807644,-0.9368710456,-1.9517802729$ $\mathrm{H}, 0,8.2326653951,-2.0714260028,-2.4430324401$ $\mathrm{H}, 0,8.0929389752,-2.2273625429,2.4091671703$ $\mathrm{H}, 0,7.522091107,-0.6539179798,4.2174890365$ $\mathrm{H}, 0,6.8318387999,1.6776039445,3.6792657388$ $\mathrm{H}, 0,6.7227231316,2.4044688588,1.3029429155$ $\mathrm{H}, 0,7.283222779,0.8373693115,-0.5041167675$ 
3. NMR spectra

${ }^{1} \mathrm{H}$ NMR of $\mathrm{X}\left(\mathrm{CDCl}_{3}\right)$

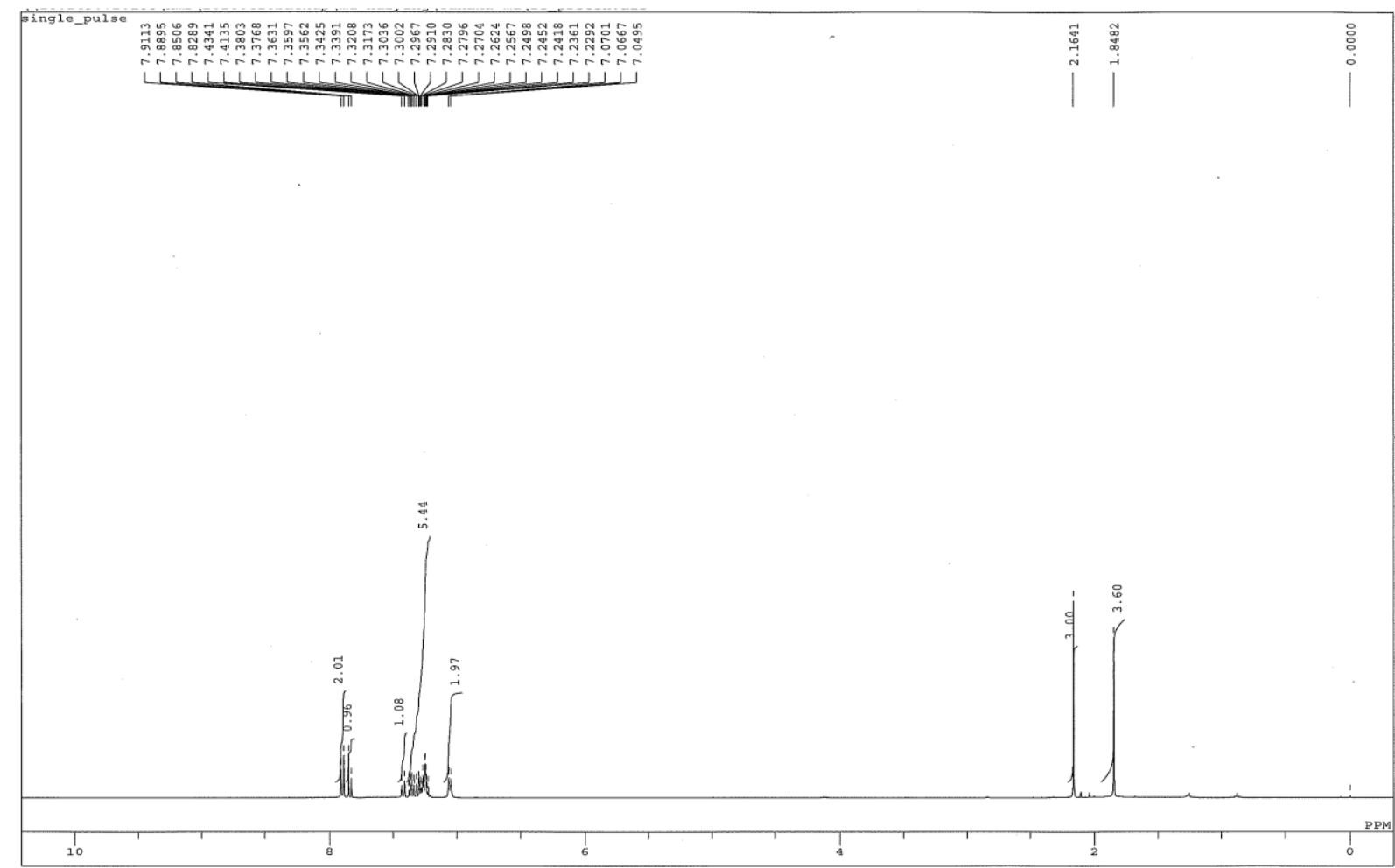

${ }^{13} \mathrm{C}$ NMR of $\mathrm{X}\left(\mathrm{CDCl}_{3}\right)$

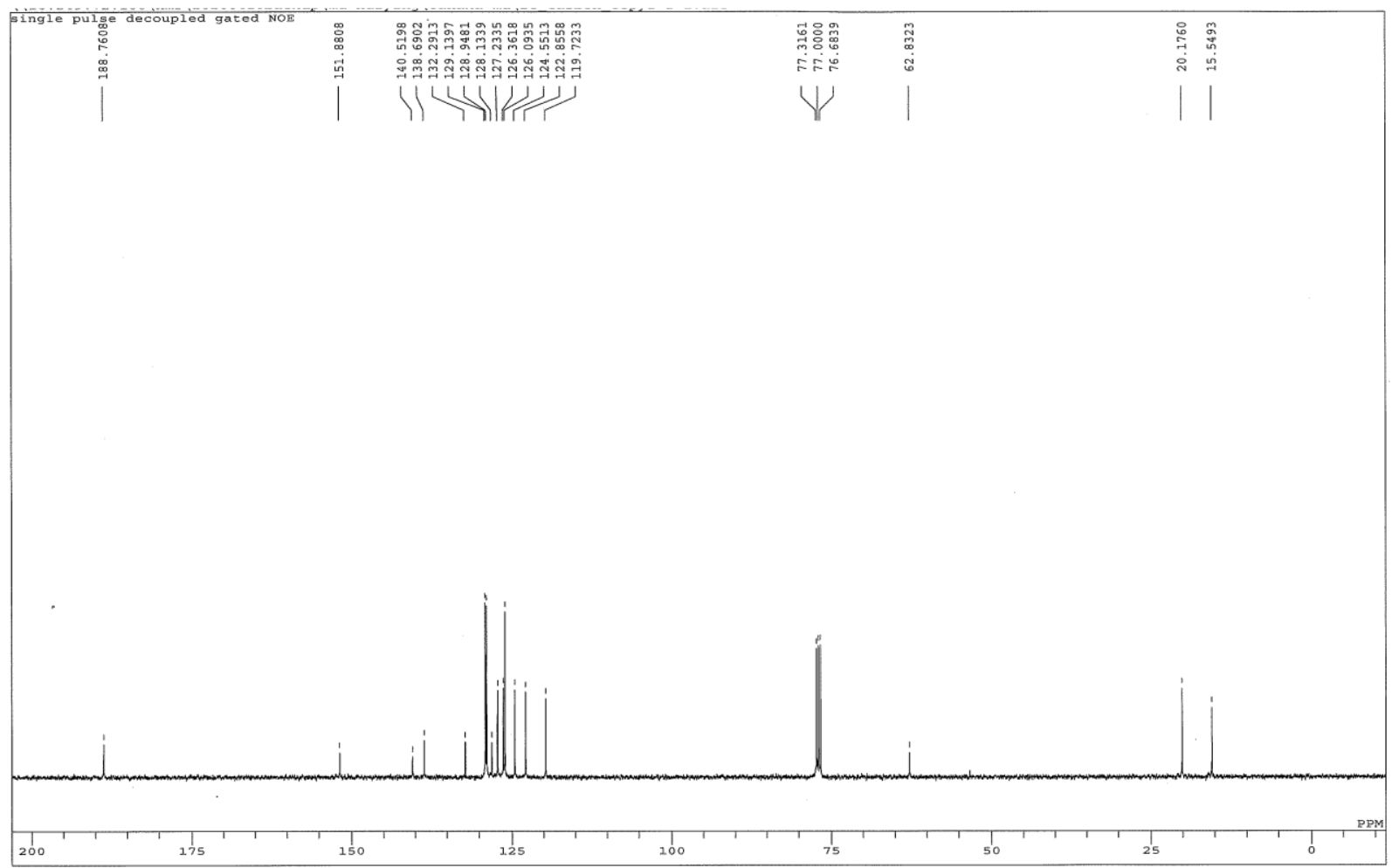


${ }^{1} \mathrm{H}$ NMR of $3\left(\mathrm{CDCl}_{3}\right)$

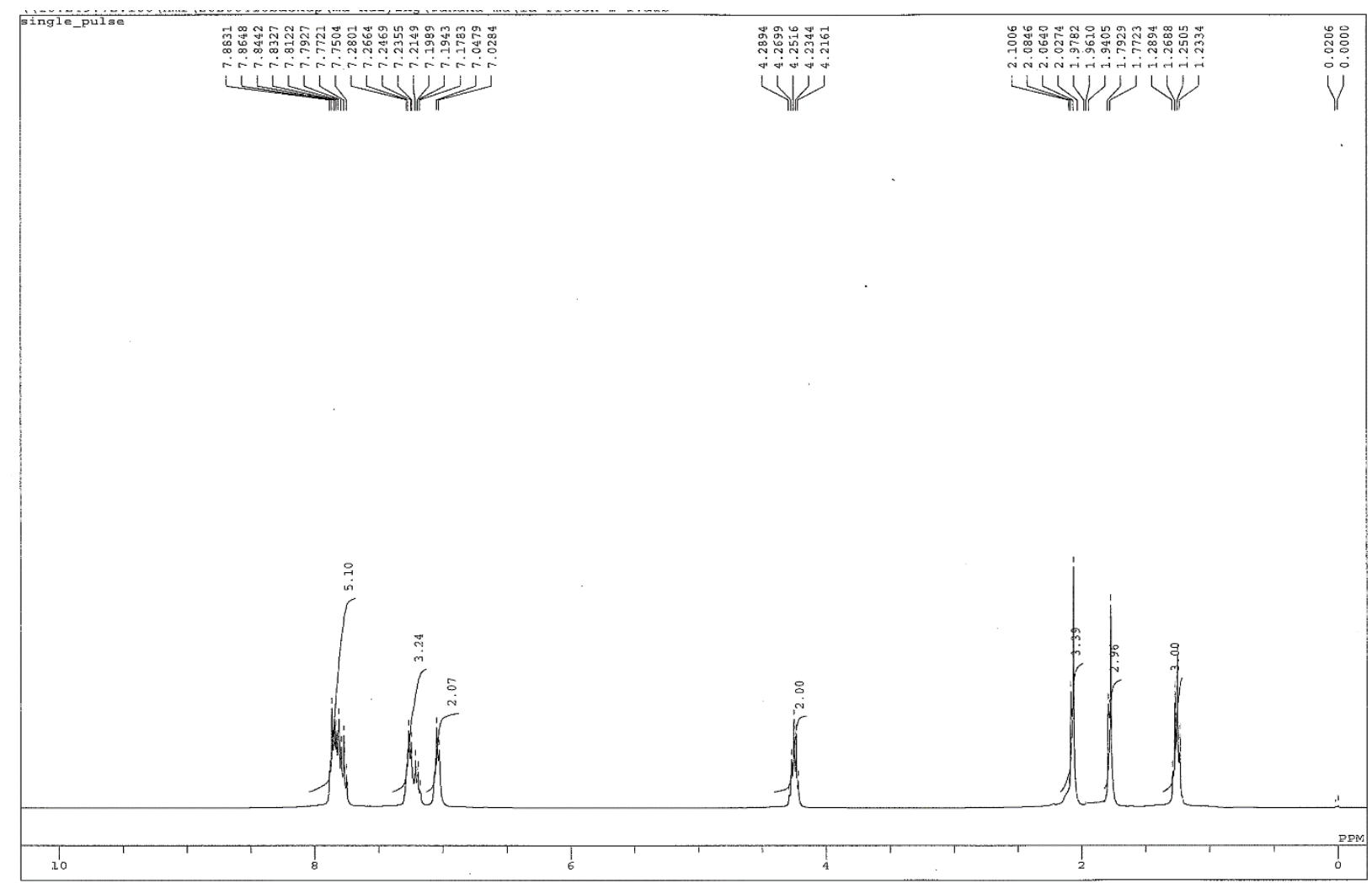

${ }^{13} \mathrm{C}$ NMR of $3\left(\mathrm{CDCl}_{3}\right)$

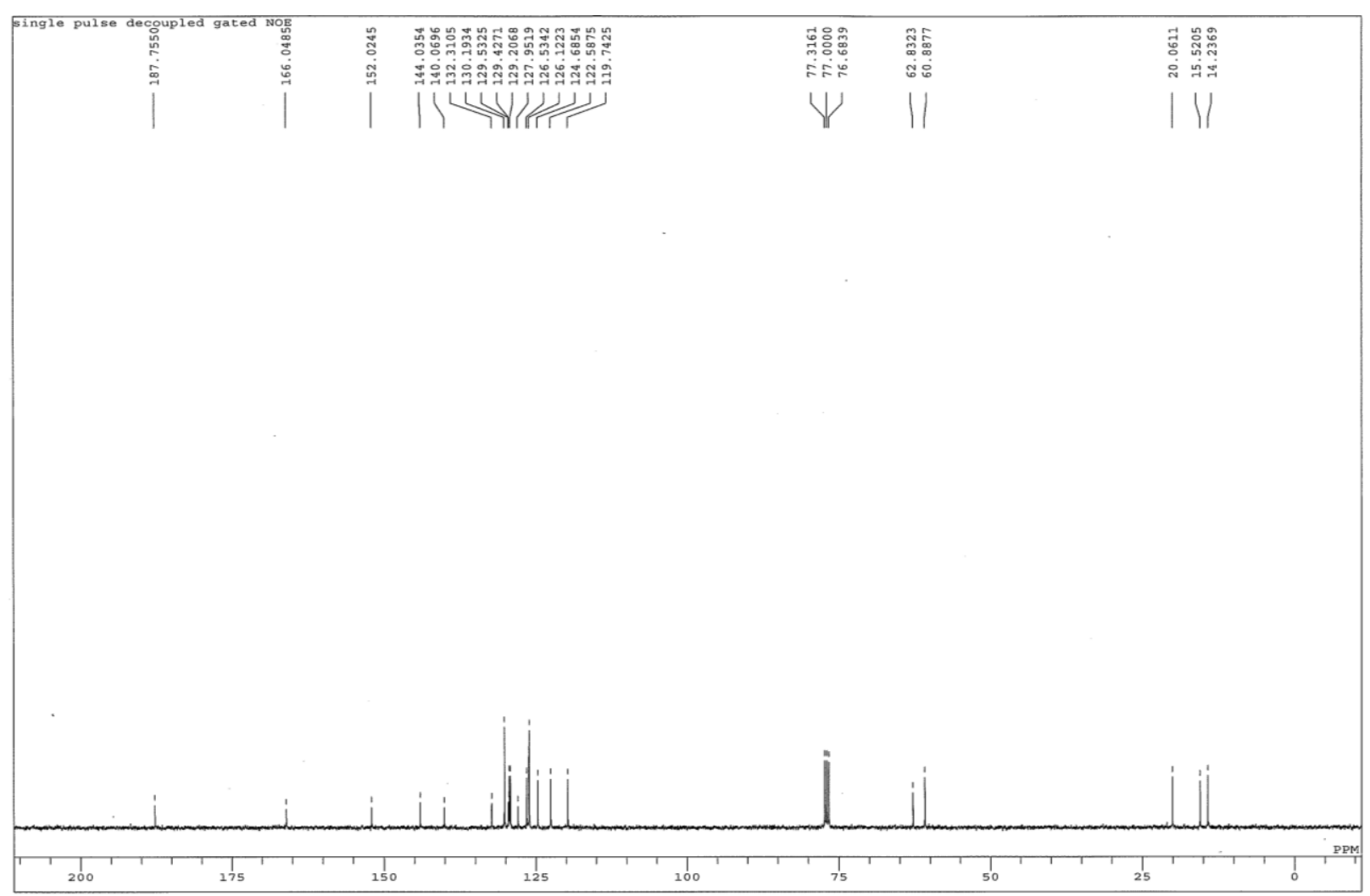


${ }^{1} \mathrm{H}$ NMR of CypH2-SAc (MeOH-d 4 )

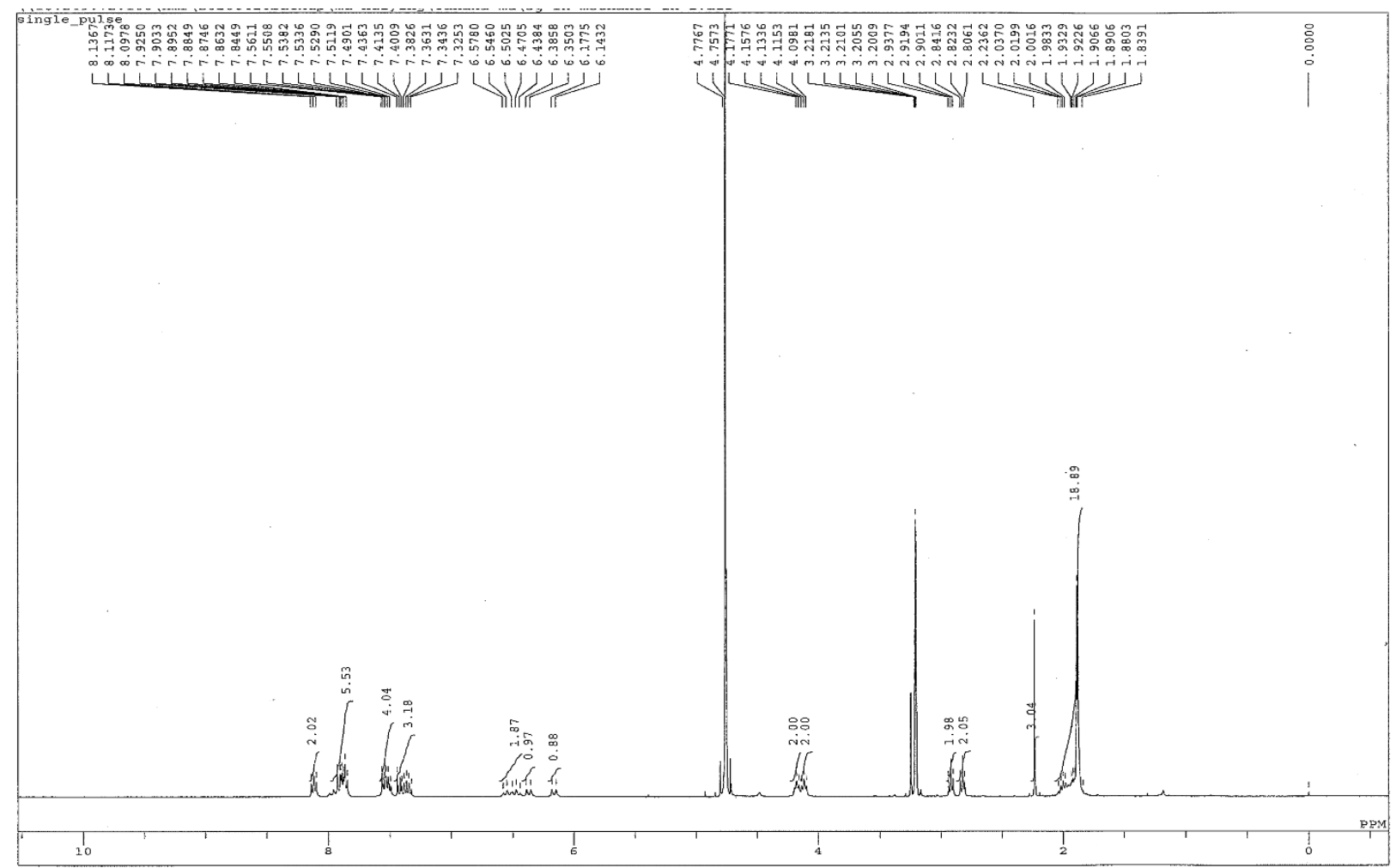

${ }^{13} \mathrm{C}$ NMR of CypH2-SAc (MeOH-d 4 )

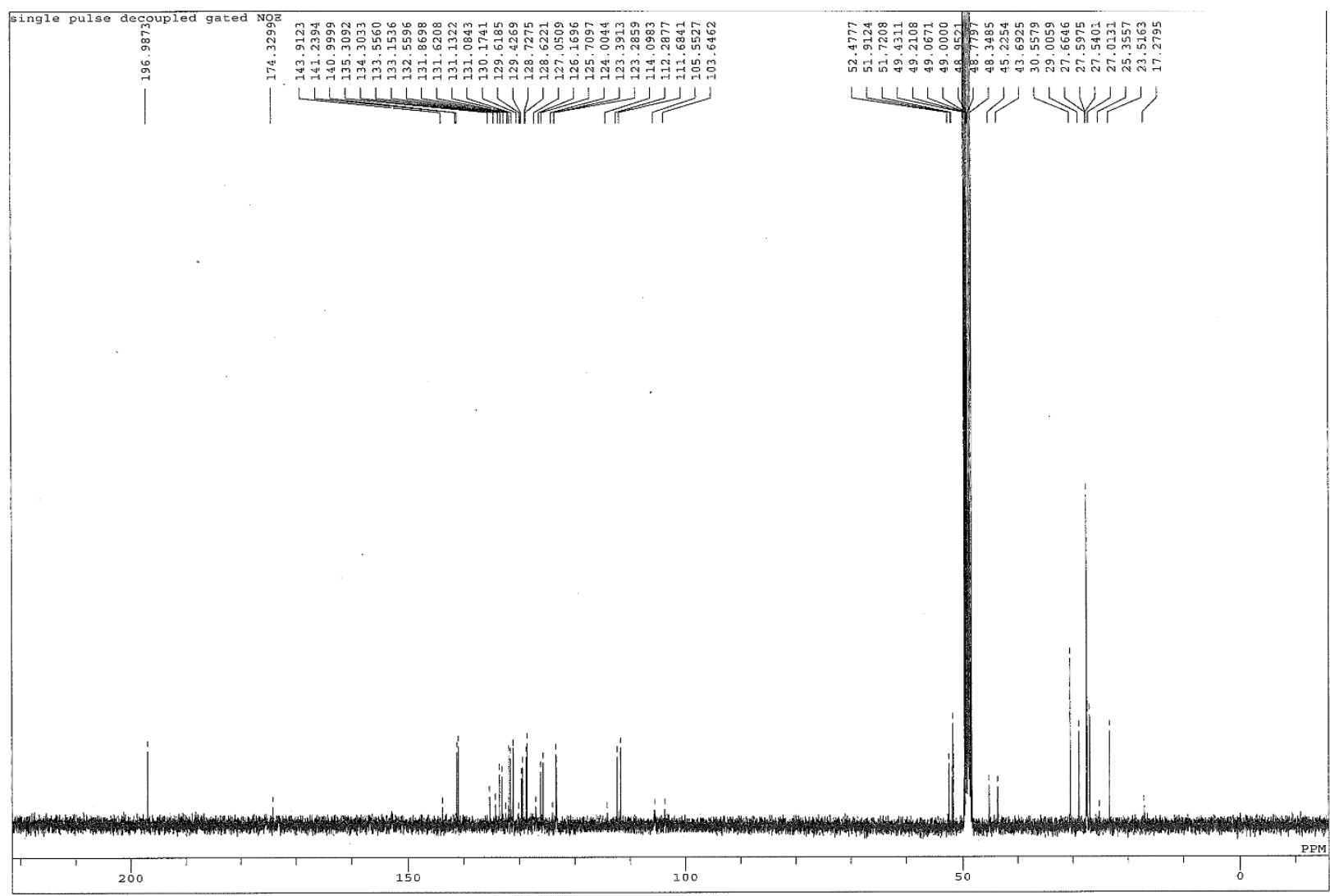


${ }^{1} \mathrm{H}$ NMR of CypH2 (MeOH-d 4 )

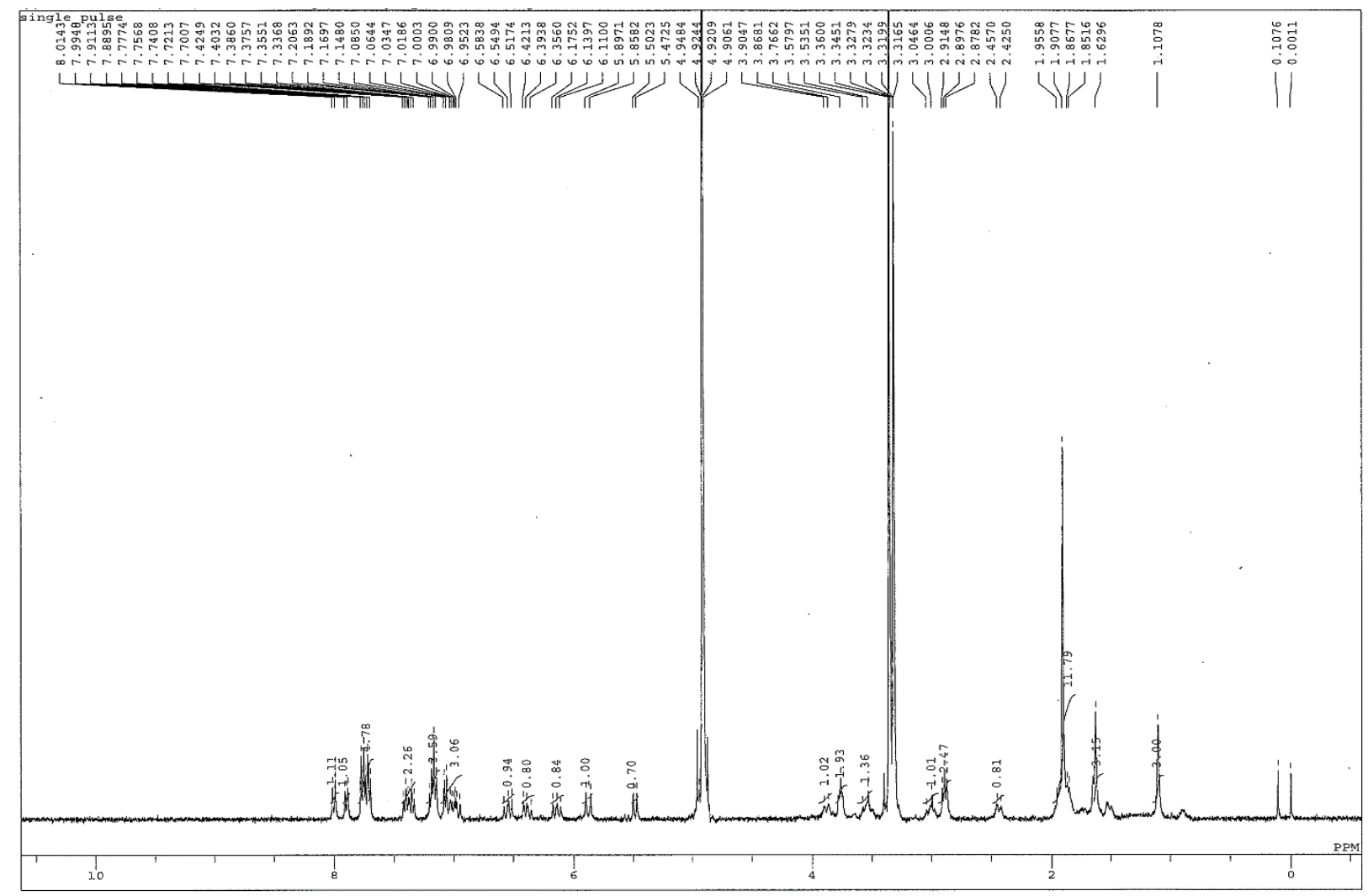

${ }^{13} \mathrm{C}$ NMR of CypH2 (MeOH-d 4 )

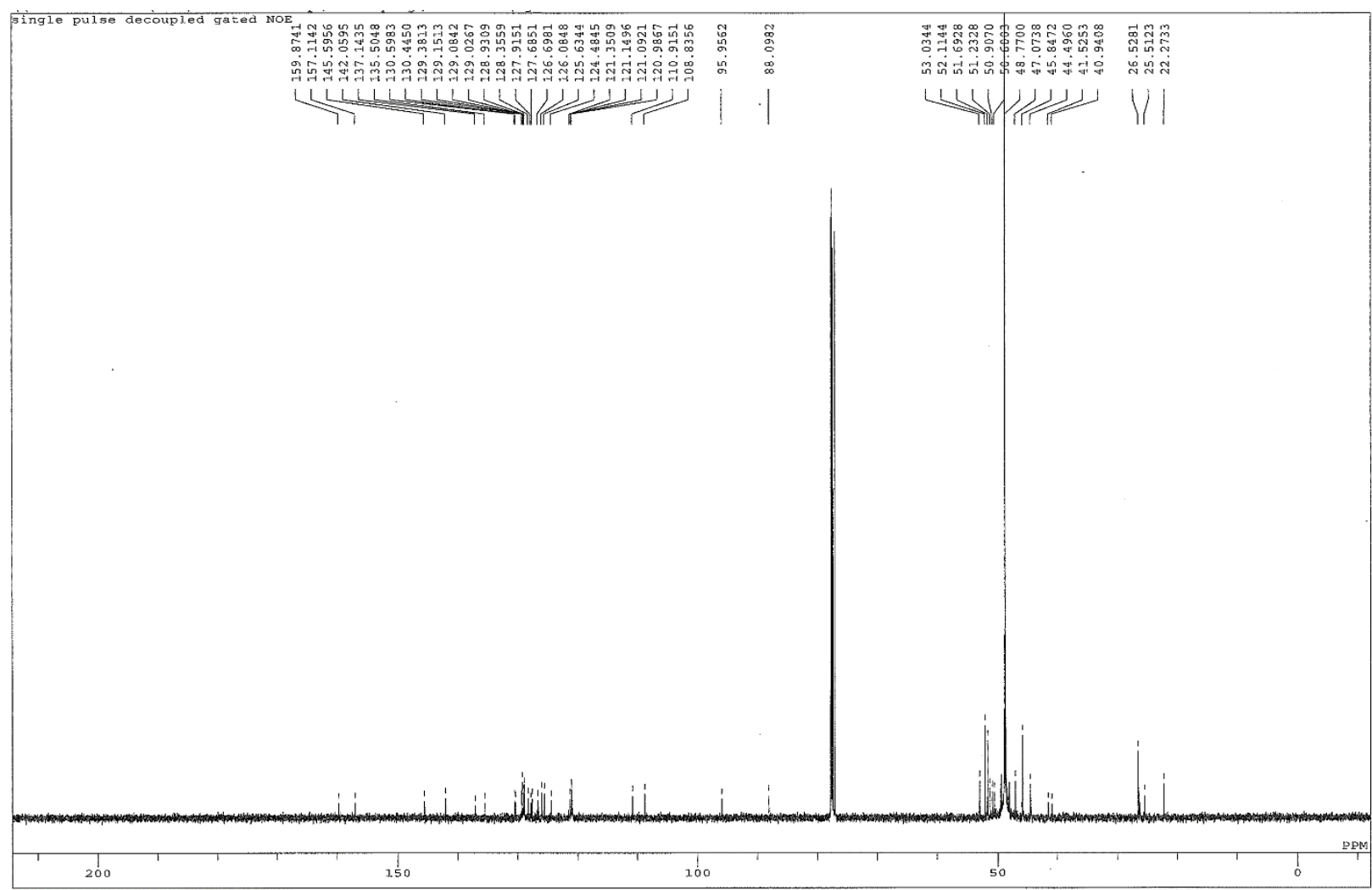


${ }^{1} \mathrm{H}$ NMR of CypH3-SAc (MeOH-d 4 )

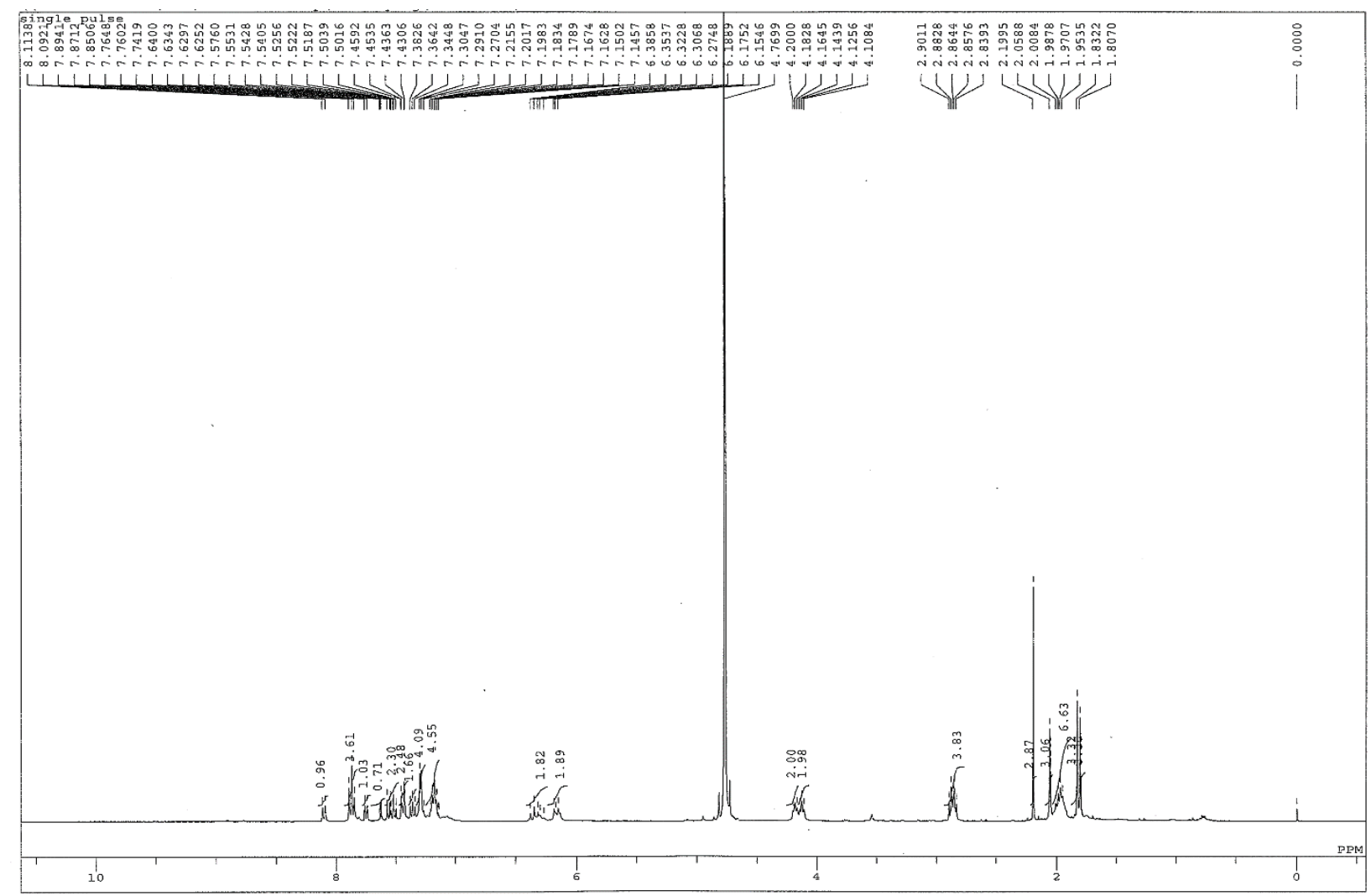

${ }^{13} \mathrm{C}$ NMR of CypH3-SAc (MeOH-d 4 )

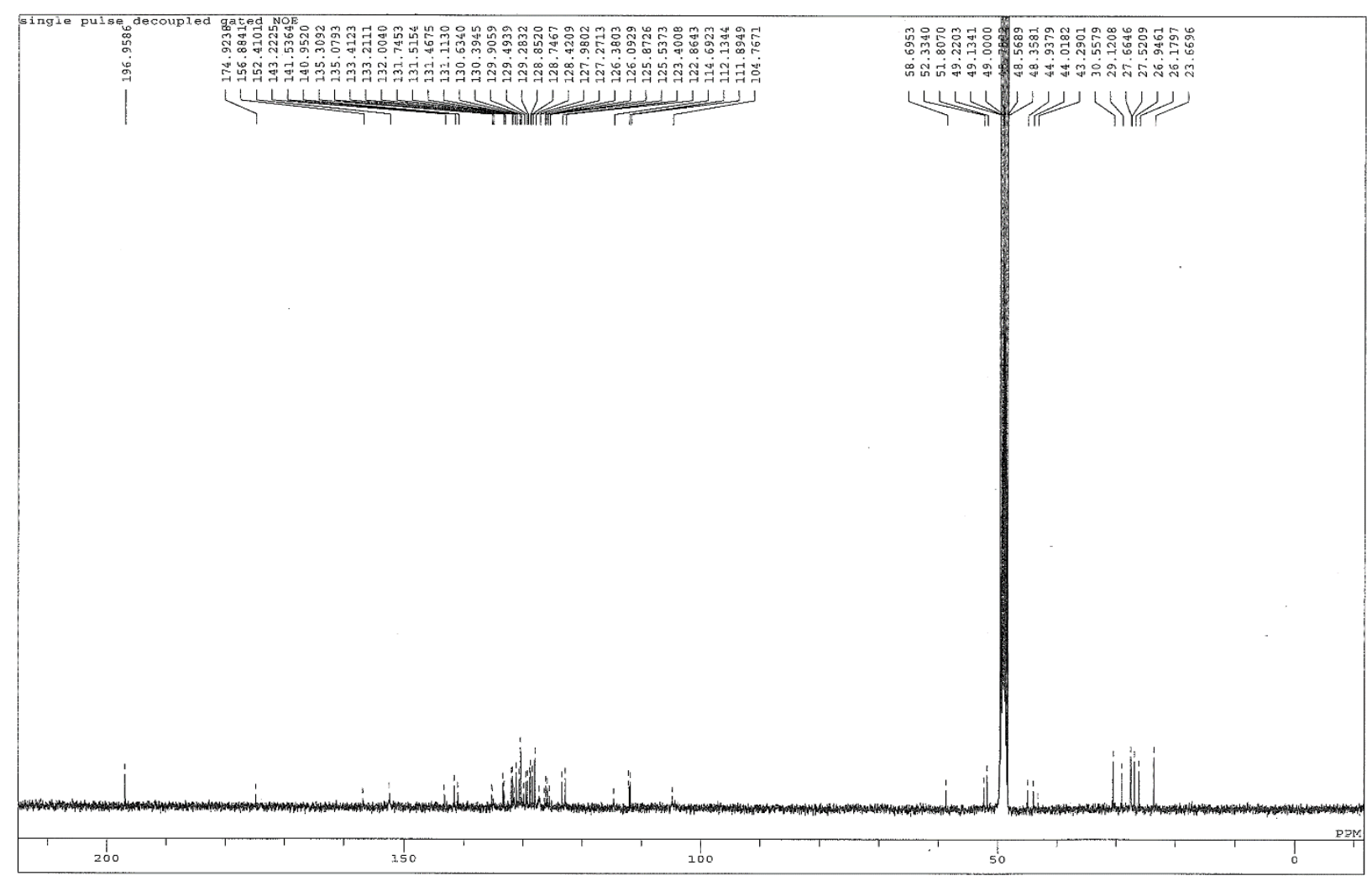




\section{${ }^{1} \mathrm{H}$ NMR of CypH3 (MeOH-d 4 )}

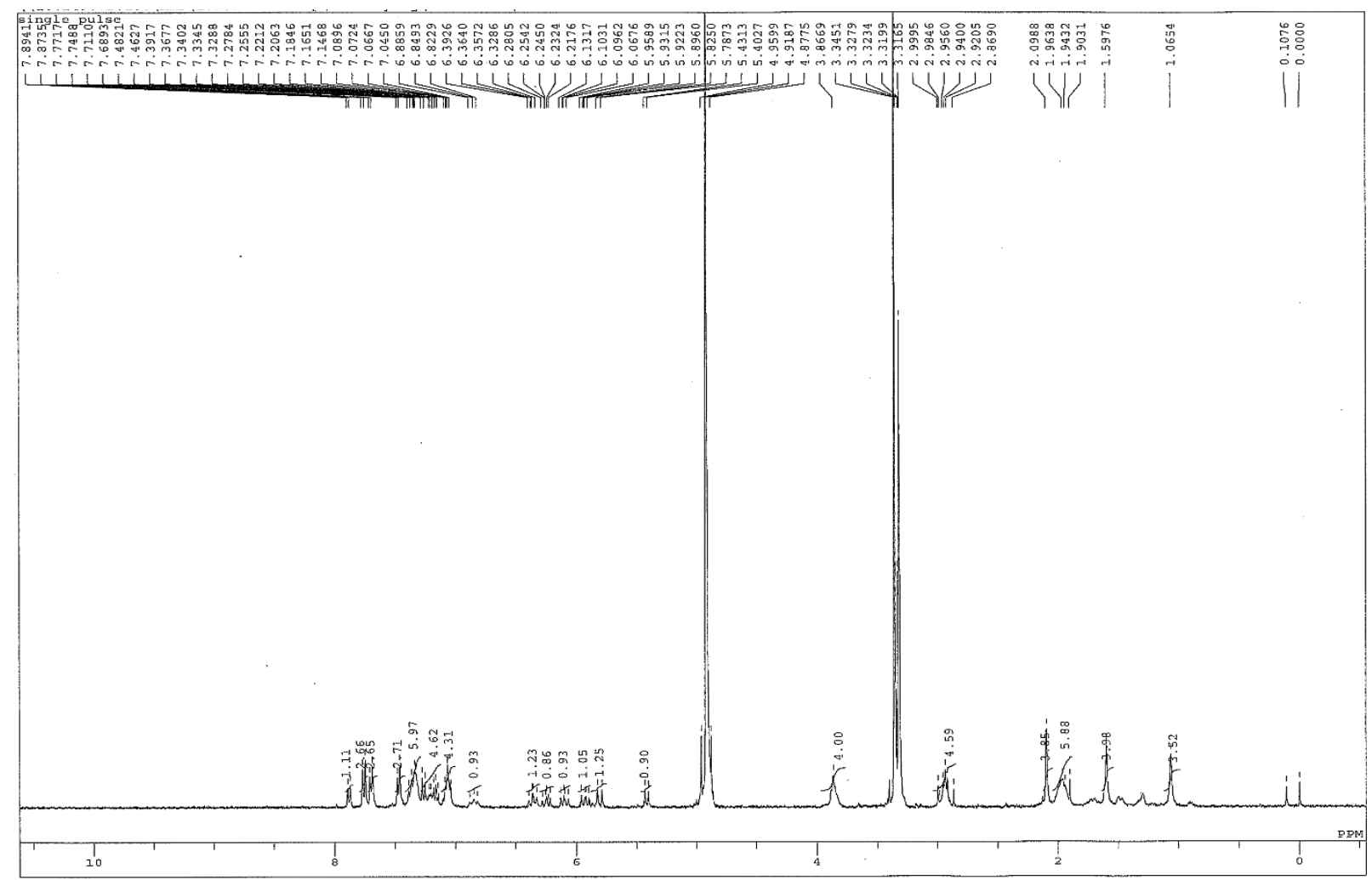

\section{${ }^{13} \mathrm{C}$ NMR of CypH3 (MeOH-d 4 )}

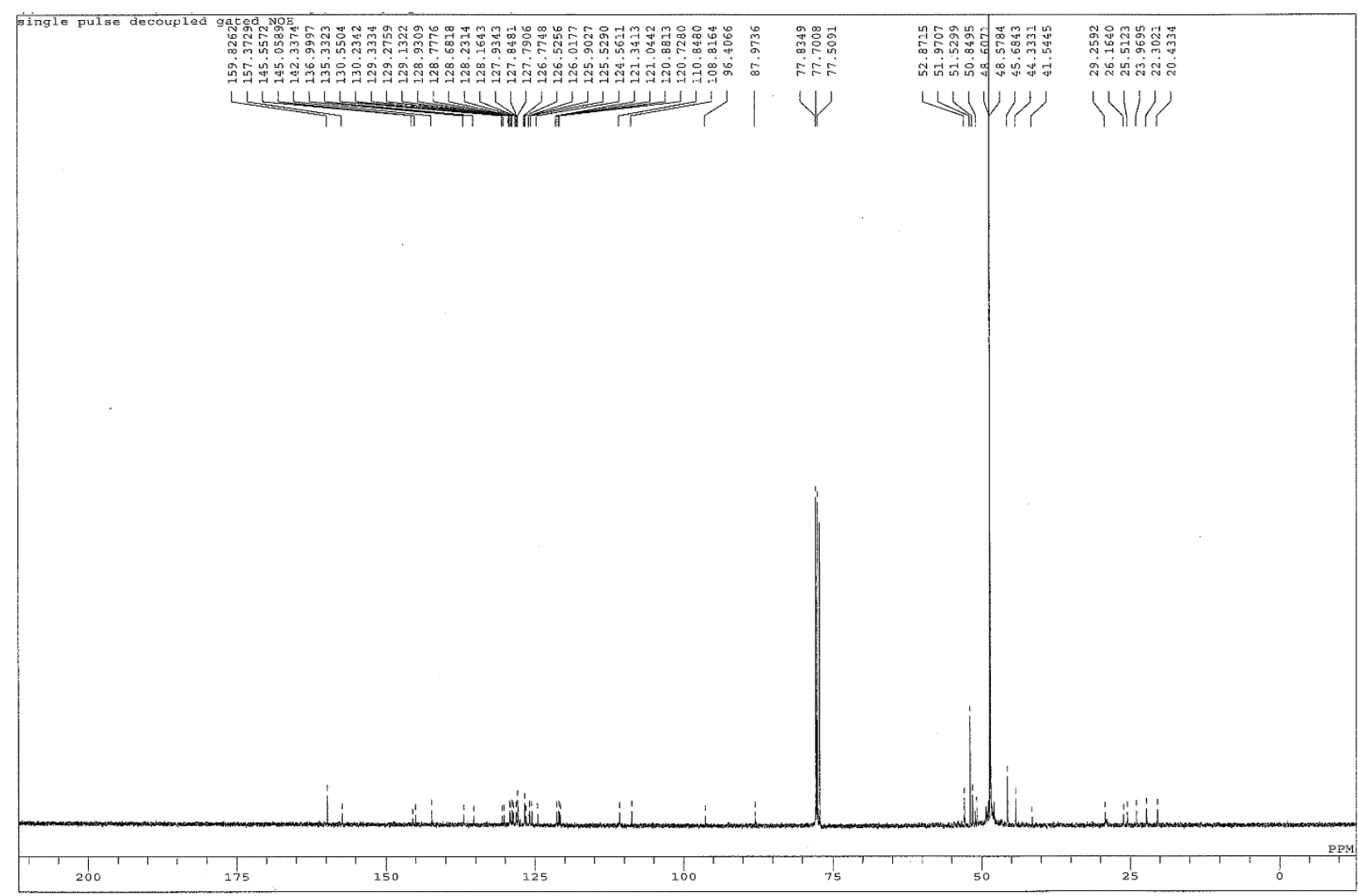


${ }^{1} \mathrm{H}$ NMR of Cy-SAc (MeOH-d 4 )

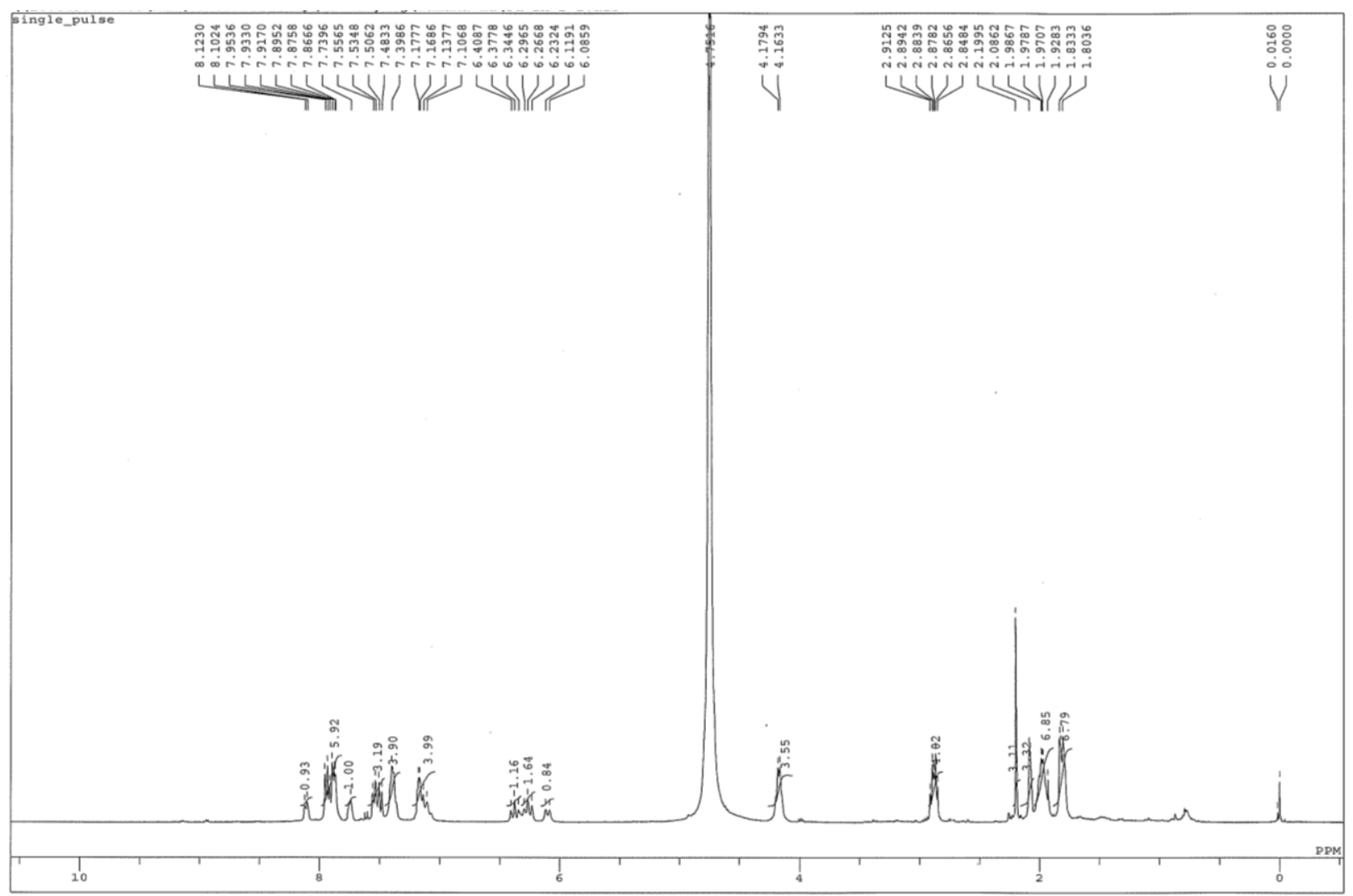

${ }^{13} \mathrm{C}$ NMR of Cy-SAc (MeOH-d 4 )

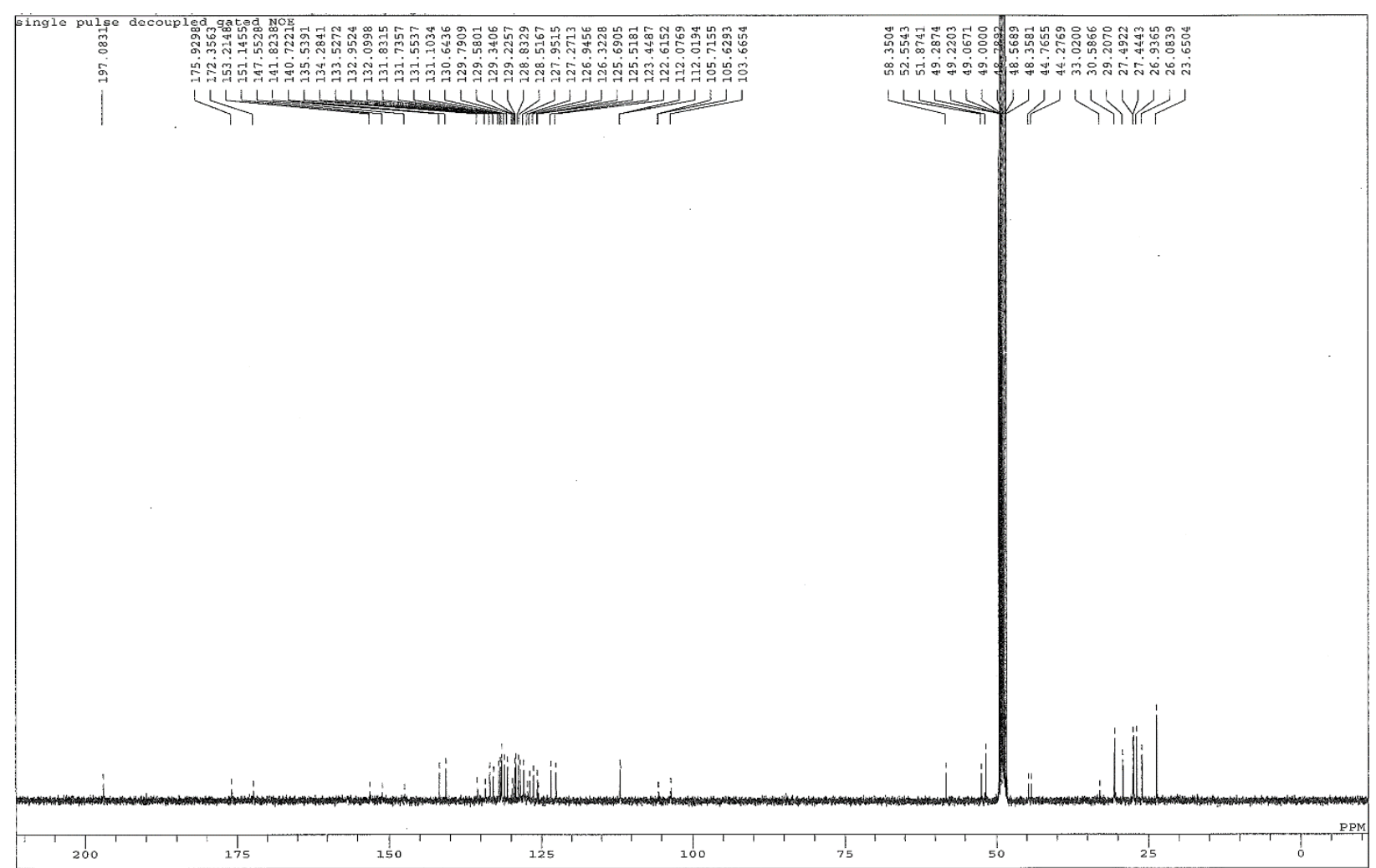


${ }^{1} \mathrm{H}$ NMR of Cy-Et (MeOH-d 4 )

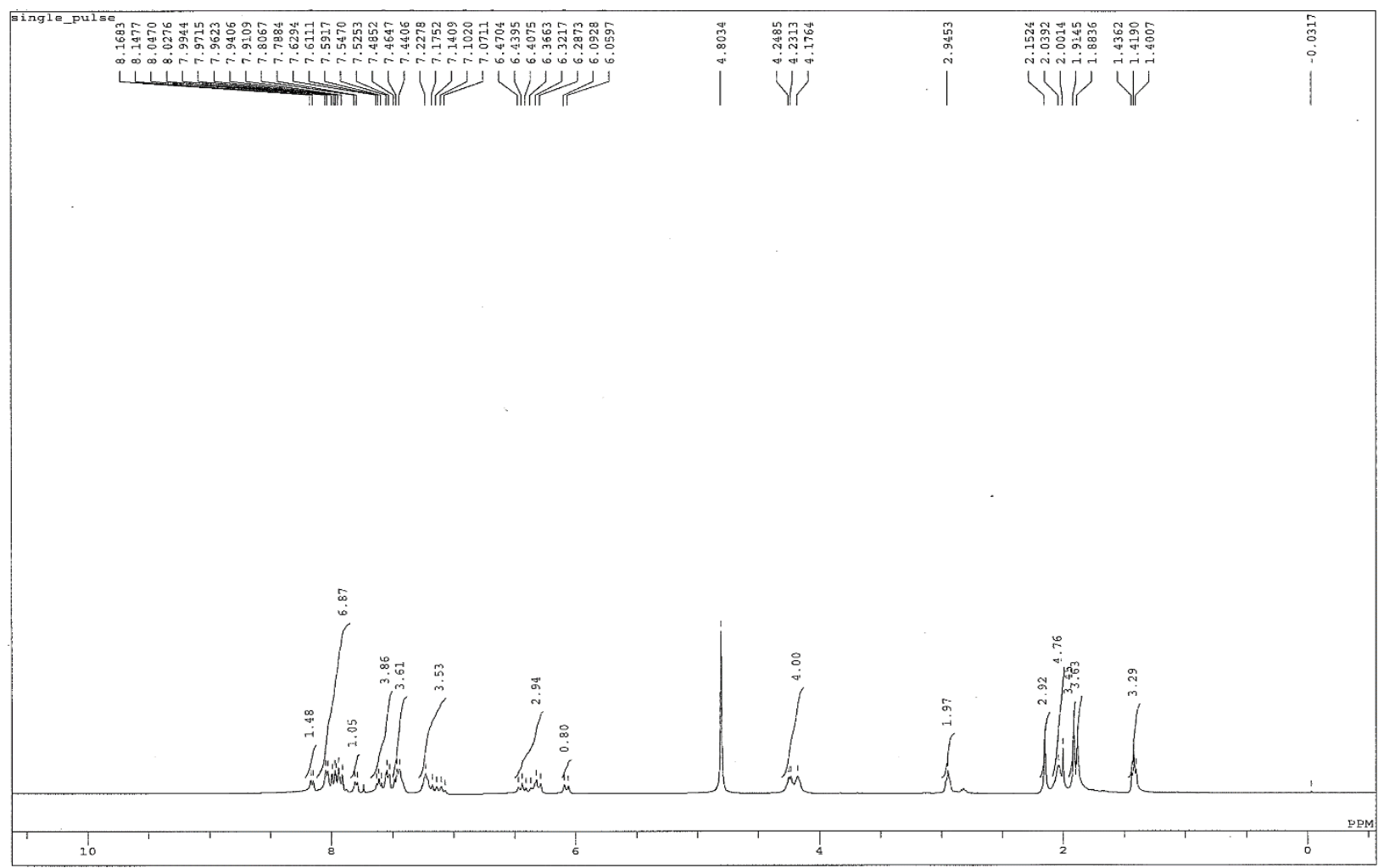

${ }^{13} \mathrm{C}$ NMR of Cy-Et (MeOH-d 4 )

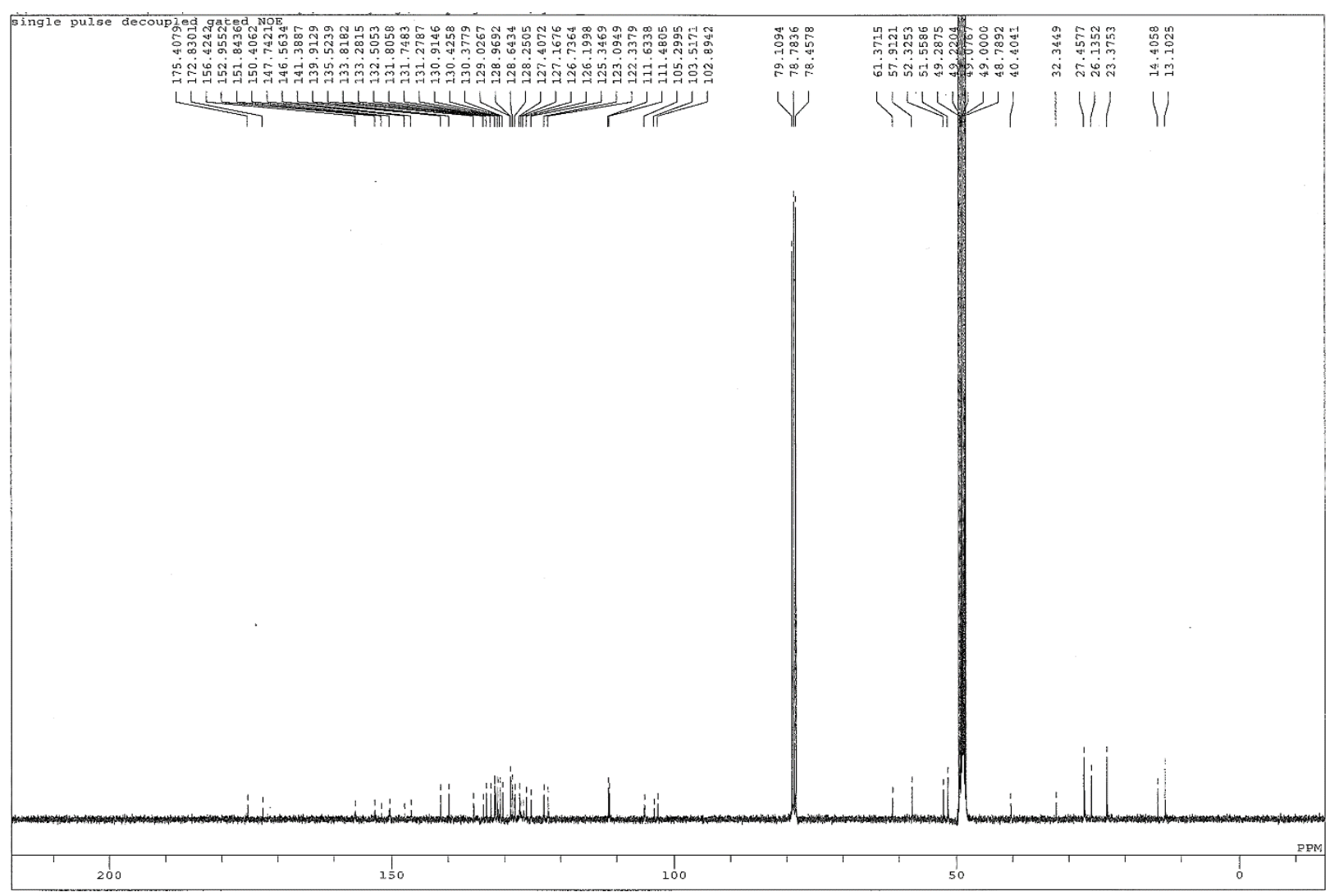

